\title{
Tanulmány
}

\author{
Bakaja Zoltán
}

\section{Átváltási müveletek a beszélőjelölőnek nevezett szanszkrit idéző mondat angol és magyar nyelvü fordításaiban}

\begin{abstract}
It is stated in Kinga Klaudy's book entitled Bevezetés a forditás gyakorlatába that specification of reporting verbs comes from the characteristics of Hungarian verbs, and the cause of their employment can be found in the stylistic conventions and translational norms. The idea of writing this study arose when I observed specification of the Sanskrit verb uvāca in an English translation of the Bhagavad-git $\bar{a}$. In the course of my research, I studied transfer operations applied in the translation of a specific Sanskrit reporting clause in a corpus which contained 33 partial or complete English, Hungarian and Hindi translations of the Bhagavad-gìtā. My research shows that in the case of the verb $u v \bar{a} c a$ there are specifications of reporting verbs in many English editions, however, in many Hungarian editions specification was not applied at all. I have also noticed that we can find specific transfer operations in the case of other words of the reporting clause as well. My study explores these cases and also points out that there are well defined translational traditions regarding the translation of the verb $u v \bar{a} c a$ both in English and Hungarian.
\end{abstract}

Keywords: Bhagavad-gītā, reporting clause, transfer operations, translational tradition, uvāca.

\section{Bevezetés}

E tanulmány elkészítésének a gondolata egy másik dolgozat írása közben merült fel bennem. Azt vizsgáltam, milyen lexikai problémákkal kell szembenéznie annak, aki Bhaktivedanta Swami Prabhupāda Bhagavad-gìtā As It Is címü könyvét akarja magyarra fordítani, s arra lettem figyelmes, hogy a szanszkrit idéző ige, az uvāca átültetése során, már az angol fordító is élt a lexikai konkretizálásnak nevezett átváltási müvelet eszközével. Klaudy Kinga azt írja Bevezetés a fordítás gyakorlatába címü könyvében, hogy az idéző igék konkretizálása a magyar ige sajátosságaiból fakad (1999: 45), s az okát a magyar stilisztikai tradíciókban kell keresnünk (1999: 49). Azt vártam, hogy csak a magyar változatban fogok konkretizálással találkozni, ezért amikor az angol szövegben is észrevettem, több angol kiadást is megvizsgáltam, hogy meglássam, elszigetelt, egyedi jelenséggel van-e dolgom. Kiderült, hogy az uvāca ige esetében sok angol fordítás tartalmaz, sok magyar pedig nem tartalmaz konkretizálást. Arra is felfigyeltem, hogy az $u v a \bar{c} a$ legtöbbször egy két- vagy háromszavas, jelölő funkciójú szerkezetben fordul elő, s a szerkezet többi tagját is meghatározott átváltási müveletek jellemzik. Tanulmányom célja e müveletek feltérképezése. 
Bakaja Zoltán:

Átváltási müveletek a beszélöjelölönek nevezett szanszkrit idézö mondat angol és magyar nyelvü fordításaiban Argumentum 15 (2019), 755-783

Debreceni Egyetemi Kiadó

DOI: 10.34103/ARGUMENTUM/2019/4

Az átváltási müveletek rendszere egy Klaudy Kinga által megalkotott, a fordítók által végzett grammatikai és lexikai müvelek típusait bemutató osztályozási keret (Klaudy 2018: 5). Klaudy definíciója szerint az átváltási müvelet „összefoglaló terminus mindazokra a rendszerszerü és rutinszerü műveletekre, amelyeket fordítók egymást követő generációi fejlesztettek ki, hogy leküzdjék a fordítás folyamatában alkalmilag együtt funkcionáló nyelvek lexikai és grammatikai rendszerének, nyelvhasználatának és kulturális kontextusának különbségeiböl fakadó nehézségeket" (Klaudy 2018: 8). E tanulmányomban nem mutatom be részletesen, csupán azonosítani fogom az egyes müveleteket, és az adott példákban releváns információkat osztom meg velük kapcsolatban. A müveletek részletes leírása megtalálható többek között Klaudy Kinga Bevezetés a forditás gyakorlatába (1999) címü könyvében, és a Simigné Fenyő Saroltával közösen írt Angol-magyar fordítástechnika címü munkájában (2007).

A Bhagavad-gītā India és a világ egyik legismertebb szentírása. Nem önálló alkotás, a Mahābhārata eposz 6. részének, Bhīṣma könyvének a 25-42. fejezete, ám jóval ismertebb és olvasottabb, mint a teljes eposz. Ennek nemcsak terjedelmi okai vannak, a Bhagavad-gìtā foglalja össze a vedák filozófiai részeinek, az upanișadoknak a tartalmát, ezért a vedāntának, India hat ortodox filozófiai iskolája egyikének is fontos alapmüve. A hagyomány szerint a könyv körülbelül ötezer évvel ezelött keletkezett, s Kṛ̣ṇa Dvaipāyana Vyāsa, az író képében megjelenő Isten munkája. Az európai nyelvek közül angolra fordították le elöször, Charles Wilkins müve 1785-ben, Londonban jelent meg. Első teljes magyar fordítását, Gömöryné Maróthy Margit munkáját 1924-ben adták ki.

Az angol fordítások száma a félezret is meghaladja, így az összeset átnézni lehetetlen lett volna - csak a saját könyvtáramban is meglévőket dolgoztam fel. Sokuk egyazon filozófiai iskola követőinek a munkája, aminek talán nyoma van bizonyos fordítási megoldásokban is. Barnett, Besant, Maharishi, Marjanovic, Sivananda és Wilkins kivételével az összes megvizsgált angol fordítás készítője a bengáli-vaiṣnava tradíció követője. Bhaktivedanta Swami Prabhupada, Nārāyaṇa Gosvāmī és Sridhar Dev-Goswami egyaránt Bhaktisiddhānta Sarasvatī Ṭhākura tanítványa. A két utóbbi szerző hindi, illetve bengáli nyelvü könyvét a saját közösségük tagjai fordították le angolra. Bhānu Swami Bhaktivedanta Swami Prabhupāda tanítványa, és Theodor Ithamar is a Bhaktivedanta által alapított ISKCON közösségének a tagja. A magyar fordítók közül Dvārakeśa, a Bhaktivedanta-fordítás magyar kiadását javító csoport tagjai és Dóka tartozik ennek az iskolának a követői közé, illetve a Bakos házaspár áll kapcsolatban vele. Vaiṣnava teológusként a gauḍ̄ya-vaiṣnavizmus a szakterületem, így az én fordításomra is ez volt a legnagyobb befolyással. Lakatos István, Szabó Lőrinc és Szerdahelyi István fordítása a költőiséget tartja szem előtt, Sebestyén Edit, Szabó Ágnes, valamint Dienes István munkája pedig más vallási közösségek könyvéül szolgál. Virág László egy minden szentírás iránt tiszteletet tanúsító fillozófiai iskola követője, Gömöryné Maróthy Margit teozófusként érdeklődött a könyv iránt, Baktay Ervinre, Kégl Sándorra és Vekerdi Józsefre pedig az indológia képviselőjeként tekinthetünk. A magyar kiadások közül az összeset áttanulmányoztam, azokat is, amelyek a teljes müvet, és azokat is, amelyek csak egy-egy részletét tartalmazzák. Kégl Sándor csak néhány szemelvényt fordított a könyvböl, a Maharishi-féle prózai fordítás a mü első hat fejezetét tartalmazza. Szabó Lőrinc csak a 11. fejezetet fordította le, Szerdahelyi István pedig több fejezetből is kiragadott néhány versszakot, s ezeket gyúrta össze egy fejezetekre nem tagolt fordítássá. Az én fordításomban a második fejezet jelent meg, egymás mellett olvasható a prózai és a verses fordítás.

A felhasznált források némelyike sokkal több, mint a Gìtā versszakainak fordítása. E müvek hosszú magyarázatokat tartalmaznak, amelyek sokszor jócskán meghaladják magának a 
Bakaja Zoltán:

Átváltási müveletek a beszélőjelölőnek nevezett szanszkrit idéző mondat angol és magyar nyelvü fordításaiban Argumentum 15 (2019), 755-783

Debreceni Egyetemi Kiadó

DOI: 10.34103/ARGUMENTUM/2019/4

költeménynek a terjedelmét. Ezeknek a könyveknek az esetében a forrásjegyzékben a magyarázatok íróját szerzőként tüntettem fel, $\mathrm{s}$ ha az angol vagy a magyar fordítás nem a kommentár szerzőjének a müve, a fordító nevét a kiadó után, zárójelben jelenítettem meg. A kommentárok írói közül Viśvanātha és Baladeva szanszkritul dolgozott, így ők nem készítettek saját fordítást. A fordító nevét akkor írtam a forrásjegyzékben szereplö tétel elejére, ha a kötetben nincsenek magyarázatok, vagy jelentőségük és terjedelmük jóval kisebb, mint a fordításé. A Lakatos \& Vekerdi és a Szerdahelyi \& Tóth párosban Vekerdi József és Tóth Edit a prózai fordítást készítette el.

Egyetlen olyan eddig megjelent magyar Bhagavad-gītāa-kiadás van, amelyet a tanulmányom nem dolgoz fel, Karma Tsering A Bhagavad Gítá ahogyan én látom (sic!) címü kiadványa (2003). Ennek egy része plágium, nagy terjedelemben, forrásmegjelölés nélkül vesz át szó szerint vagy kisebb változtatásokkal a Dvārakeśa-fordítás szövegéből, ahol pedig saját anyagot tartalmaz, ott annyira eltér az eredeti mütől, hogy aligha lehet fordításnak nevezni.

\section{A beszélőjelölö fogalma}

Az idéző mondat azon formáját nevezem beszélőjelölőnek, amelyet a Mahābhāratában, az upanișadok némelyikében (hamsa, muktika, rāmarahasya, śukarahasya) és a purāṇákban használnak, de a Rāmāyanában például nem találhatjuk meg. Nem tartozik szervesen a szöveghez, annak többi részétől eltérően nem valamely versmértékben íródott, és néhány kiadásban több, másokban kevesebb van belöle. Ahogy már korábban írtam, vizsgálódásaimat az uvāca fordítási példáival kezdtem. Ez az igealak 64-szer fordul elő a Bhagavad-gìtāban. (A Bhaktivedanta-kiadás szanszkritját választottam a számlálás alapjának, egyes kiadásokban ez a szám eltérhet.) Gyöke a vac, s a Gĩtāban használatos alak az ebből a gyökből képzett 2. ragozási osztályú, E/3 személyü ige elbeszélő múlt idejü (befejezett) formája. A vac jelentését Körtvélyesi gyöktáblázata (2006: 255) a 'beszél' magyar megfelelővel adja vissza, a MonierWilliams szótárban (2011) található angol fordításai a következők: speak, say, tell, utter, announce, declare, mention, proclaim, recite, describe. (A továbbiakban minden szanszkrit szó jelentését innen idézem.) A gyökből képzett igének a Bhagavad-gītāban használt leggyakoribb angol fordítása a said.

Az uvāca szó maguknak a versszakoknak a szövegében csak 4-szer van jelen, a müben szereplő többi 60 alakja egy alany+uvāca vagy jelző+alany+uvāca felépítésủ szerkezetben található meg, amely megelőzi az egyes versszakokat. A szerkezet funkciója a beszélő személyének megmutatása, ezért beszélőjelölőnek neveztem el. Nem mondhatjuk el, hogy a jelölő minden egyes új megszólalás előtt felbukkan, de majdnem mindegyik előtt ott találjuk. Formális jellegét, azaz pusztán jelölői szerepét az bizonyítja, hogy sokszor még azok után a versszakok után is ott áll, amelyek konkrétan megnevezik, hogy a következő ślokában ki fog beszélni (1.26-27, 2.1-2, 2.10-11). A beszélöjelölö jelentése tehát '(A nagytiszteletü) X. Y. mondta'. A Bhagavad-gītāban négy szereplő megszólalása előtt található meg, vagyis az itt vizsgált négy idéző mondat a (1) dhṛtarāștra uvāca, (2) sañjaya uvāca, (3) arjuna uvāca és a (4) śrī-bhagavān uvāca. 


\section{$3 \quad$ A beszélőjelölö jelzőjének fordítása}

A beszélőjelölő jelzője a śrī, amelynek jelentése 'ragyogó, sugárzó, nagyszerü, tiszteletre méltó, tisztelendő'. A tisztelet kifejezésére szolgáló megszólításként használják. A Bhagavadgìtában csak Isten nevéhez kapcsolódóan találhatjuk meg, de más könyvekben szentek s akár démoni királyok neve előtt is felfedezhetjük. Ez az a tagja a beszélőjelölőnek, amelynek esetében a fordítók leginkább élnek a kihagyás lehetőségével.

\subsection{A beszélöjelölö jelzöje az angol fordításokban}

Bár ez az alfejezet a beszélőjelölö jelzőjének az angol fordításáról szól, itt említem meg a hindi kiadást is (1. URL), amelyben a szó változatlanul szerepel. A Glosbe hindi-magyar szótár szerint a hindi śrī jelentése 'úr, uram' (2. URL). Talán a hindi és szanszkrit formális azonosságnak köszönhető, hogy a Nārāyaṇa-kiadás fordítója a jelző angol szövegbe való átültetéséhez az idegen szóként való átvételt választotta, a szövegben mindvégig a Srī Bhagavān said szerepel.

Besant (1905), Maharishi (1967) Sivananda (2000) és Ithamar (2010) a śrī-bhagavān uvāca fordítására következetesen a the blessed Lord said formulát alkalmazta $\mathrm{s}$ a Bhaktivedanta-fordítás első kiadásában (1968) is sok helyen ez szerepelt $(2.11,2.55,3.3$, 3.37, 4.1, 4.5, 5.2, 6.1, 6.35, 6.40, 10.19, 11.5, 11.32, 11.47, 11.52, 12.2, 13.2, 14.1, 14.22, 15.1, 16.1). Bhaktivedanta Swami Prabhupāda a śrī jelentését néhány más könyvében is a blessed-del adta vissza (3. URL). Ezt egyszerü behelyettesítésnek tekinthetjük.

„Gyakran maradnak ki a fordításból a megszólítások, udvariassági formák, mivel a különböző kultúrákra jellemző és különböző történelmi korszakokhoz kötődő megszólításokat és udvariassági formákat szinte lehetetlenség megfeleltetni egymásnak" - írja Klaudy (1999: 90). A beszélőjelölő jelzője teljesen kimarad Bhānu, Bhumipati, Marjanovic, Sagar, Swarupananda, Barnett és Wilkins fordításából. A Bhaktivedanta-fordítás második kiadásában is csak kétszer találhatjuk meg - lefordítatlanul: $(4.1,6.35)$.

\subsection{A beszélöjelölö jelzöje a magyar fordításokban}

A beszélőjelölő jelzője Baktay, Dóka, Gömöryné, Kégl, Lakatos, Szabó Lőrinc, Szerdahelyi, Vekerdi és Virág fordításából teljesen kimaradt. Ez nem jelenti azt, hogy a fordítók mindegyike végrehajtotta a kihagyás müveletét. Dóka, Szabó Lőrinc és Virág olyan angol fordításból dolgoztak, amelyben már megtörtént a jelző kihagyása. Lakatos és Szerdahelyi Vekerdi és Tóth nyersfordítását használta. Ezeket nem láttam, de Vekerdi később kiadott prózai fordítása sem tartalmazza a jelölö jelzőjét. Így Baktayról, Gömörynéröl, Kéglröl, Vekerdiről és egy versszaknál (8.3) a Bakos házaspárról mondhatjuk el biztosan, hogy ebben az esetben a lexikai átváltási mủveletek közül a kihagyással élt. Az én prózai fordításomban egy helyen (2.2) a teljes beszélőjelölő kimaradt, mert a megelőző versszakból már megtudtuk, hogy ki fog beszélni. Az 1. táblázat a jelző kihagyásával létrejött magyar mondatokat mutatja be. Ezek közül néhányban az ige is kimaradt. 
Bakaja Zoltán:

Átváltási müveletek a beszélőjelölönek nevezett szanszkrit idézö mondat angol és magyar nyelvü forditásaiban Argumentum 15 (2019), 755-783

Debreceni Egyetemi Kiadó

DOI: 10.34103/ARGUMENTUM/2019/4

\begin{tabular}{|l|l|l|}
\hline \multicolumn{1}{|c|}{ Fordító } & \multicolumn{1}{c|}{ Forrásnyelvi szöveg } & \multicolumn{1}{c|}{ Célnyelvi szöveg } \\
\hline Kégl (1910) & śri-bhagavān uvāca & Az istenség így szólt: \\
\hline Gömöryné (1924) & The blessed Lord said & Krisna szól: / Krisna. \\
\hline Vekerdi (1997) & śri-bhagavān uvāca & A Magasztos szólt: \\
\hline Baktay (2013) & śri-bhagavān uvāca & A Magasztos: \\
\hline Bakaja (2016) & śri-bhagavān uvāca & - mondta a fenséges Úr. \\
\hline Bakaja (2016) & śrì-bhagavān uvāca & $\begin{array}{l}\text { Az Úr, akinél senki sem gazdagabb, erösebb, híresebb, szebb, } \\
\text { akinél nem tud többet senki, s aki könnyedén lemond } \\
\text { mindenéröl, így válaszolt: }\end{array}$ \\
\hline Bakos és Bakos (2017) & śrì-bhagavān uvāca & Az Úr válaszolt: \\
\hline
\end{tabular}

1. táblázat. A jelzö kihagyásának eredményeként keletkezett magyar idéző mondatok

A jelző Sebestyén munkájában, a Sivánanda-kiadásban, a Bhaktivedanta-fordítás első kiadásában, a Bakos házaspár fordításában és a csak az első hat fejezetet tartalmazó Maharishi-kiadásban jelenik meg magyarra fordítva. A következő táblázat bemutatja az említett müvekben a śrī-bhagavān kifejezés megfelelőit, amelyekben a jelző fordítását vastaggal szedtem. A Bhaktivedanta-fordítás esetében az angol eredetit is feltüntettem, és jeleztem, ha az első angol kiadás rövidített és teljes változata eltér egymástól. A fejlécben a fordító neve olvasható. A név utáni kérdőjel azért van ott, mert a 2. és 3. magyar kiadáson Dvārakeśa már nem dolgozott, és nehéz lenne kideríteni, hogy a fordítócsoport tagjai közül kinek a nevéhez füződik valamely változtatás. A '—' jel azt jelenti, hogy a jelölő hiányzik a fordításból. A Maharisiés a Sivánanda-kiadás nem szerepel a táblázatban, mert azokban a jelzőt kivétel nélkül minden esetben az 'áldott' szóval fordítják. 
Bakaja Zoltán:

Átváltási müveletek a beszélőjelölőnek nevezett szanszkrit idézö mondat angol és magyar nyelvü fordításaiban

Argumentum 15 (2019), 755-783

Debreceni Egyetemi Kiadó

DOI: 10.34103/ARGUMENTUM/2019/4

\begin{tabular}{|c|c|c|c|c|}
\hline Versszak & $\begin{array}{l}\text { Dvārakeśa 1. (Bhaktivedanta é. n.) } \\
\text { Bhaktivedanta }(1968,1972)\end{array}$ & $\begin{array}{c}\text { Dvārakeśa }+ \text { ? (Bhaktivedanta 2001, 2014) } \\
\text { Bhaktivedanta (2015) }\end{array}$ & Sebestyén (2000) & $\begin{array}{l}\text { Bakos és Bakos } \\
(2017)\end{array}$ \\
\hline 2.2 & $\begin{array}{l}\text { Bhagavān, a Legfelsőbb Személy... } \\
\text { 68: The Supreme Personality... } \\
\text { 72: The Supreme Person [Bhagavān] ... }\end{array}$ & $\begin{array}{l}\text { Az Istenség Legfelsőbb Személyisége... } \\
\text { The Supreme Personality of Godhead... }\end{array}$ & - & A Magasztos Úr... \\
\hline 2.11 & $\begin{array}{l}\text { A Magasztos Úr... } \\
\text { The Blessed Lord... }\end{array}$ & $\begin{array}{l}\text { Az Istenség Legfelsőbb Személyisége... } \\
\text { The Supreme Personality of Godhead }\end{array}$ & A Magasztos Úr... & A Magasztos Úr... \\
\hline 2.55 & $\begin{array}{l}\text { A Magasztos Úr... } \\
\text { The Blessed Lord... }\end{array}$ & $\begin{array}{l}\text { Az Istenség Legfelsőbb Személyisége... } \\
\text { The Supreme Personality of Godhead }\end{array}$ & A Magasztos Úr... & A Magasztos Úr... \\
\hline 3.3 & $\begin{array}{l}\text { Az Istenség Legfelsőbb Személyisége... } \\
\text { The Blessed Lord... }\end{array}$ & $\begin{array}{l}\text { Az Istenség Legfelsőbb Személyisége... } \\
\text { The Supreme Personality of Godhead }\end{array}$ & Bhagawan Krishna.. & ... a Magasztos Úr.. \\
\hline 3.37 & $\begin{array}{l}\text { A Magasztos Úr... } \\
\text { The Blessed Lord... }\end{array}$ & $\begin{array}{l}\text { Az Istenség Legfelsőbb Személyisége... } \\
\text { The Supreme Personality of Godhead }\end{array}$ & Bhagawan... & A Magasztos Úr... \\
\hline 4.1 & $\begin{array}{l}\text { Az Istenség Legfelsőbb Személyisége... } \\
\text { The Blessed Lord... }\end{array}$ & $\begin{array}{l}\text { Az Istenség Legfelsőbb Személyisége, az Úr Śrī Krṣna... } \\
\text { The Personality of Godhead, Lord Ś̉ Krịna... }\end{array}$ & A Magasztos Úr... & A Magasztos Úr... \\
\hline 5.2 & $\begin{array}{l}\text { A Magasztos Úr... } \\
\text { The Blessed Lord... }\end{array}$ & $\begin{array}{l}\text { Az Istenség Legfelsőbb Személyisége... } \\
\text { The Personality of Godhead... }\end{array}$ & A Magasztos Úr... & A Magasztos Úr... \\
\hline 6.1 & $\begin{array}{l}\text { A Magasztos Úr... } \\
\text { The Blessed Lord... }\end{array}$ & $\begin{array}{l}\text { Az Istenség Legfelsőbb Személyisége... } \\
\text { The Supreme Personality of Godhead... }\end{array}$ & A Magasztos Úr... & A Magasztos Úr... \\
\hline 6.35 & $\begin{array}{l}\text { A Magasztos Úr... } \\
\text { The Blessed Lord... }\end{array}$ & $\begin{array}{l}\text { Az Úr Śrī Krșṇa... } \\
\text { Lord Śrī Krṣna... }\end{array}$ & Az Úr Krishna... & A Magasztos Úr... \\
\hline 6.40 & $\begin{array}{l}\text { A Magasztos Úr... } \\
\text { The Blessed Lord... }\end{array}$ & $\begin{array}{l}\text { Az Istenség Legfelsőbb Személyisége... } \\
\text { The Supreme Personality of Godhead... }\end{array}$ & A Magasztos Úr... & ... a Magasztos Úr.. \\
\hline 7.1 & $\begin{array}{l}\text { A Magasztos Úr... } \\
68,72: \text { kimaradt... }\end{array}$ & $\begin{array}{l}\text { Az Istenség Legfelsőbb Személyisége... } \\
\text { The Supreme Personality of Godhead }\end{array}$ & A Magasztos Úr... & A Magasztos Úr... \\
\hline
\end{tabular}


Bakaja Zoltán:

Átváltási müveletek a beszélöjelölőnek nevezett szanszkrit idéző mondat angol és magyar nyelvü fordításaiban

Argumentum 15 (2019), 755-783

Debreceni Egyetemi Kiadó

DOI: 10.34103/ARGUMENTUM/2019/4

\begin{tabular}{|c|c|c|c|c|}
\hline Versszak & $\begin{array}{c}\text { Dvārakeśa 1. (Bhaktivedanta é. n.) } \\
\text { Bhaktivedanta }(1968,1972)\end{array}$ & $\begin{array}{c}\text { Dvārakeśa }+ \text { ? (Bhaktivedanta 2001, 2014) } \\
\text { Bhaktivedanta (2015) }\end{array}$ & Sebestyén (2000) & $\begin{array}{l}\text { Bakos és Bakos } \\
(2017)\end{array}$ \\
\hline 8.3 & $\begin{array}{l}\text { A Legfelsöbb Személy... } \\
\text { 68: The Supreme Personality of Godhead... } \\
\text { 72: The Supreme Lord... }\end{array}$ & $\begin{array}{l}\text { Az Istenség Legfelsőbb Személyisége... } \\
\text { The Supreme Personality of Godhead... }\end{array}$ & Az Áldott Úr... & - \\
\hline 9.1 & $\begin{array}{l}\text { A Legfelsőbb Személy... } \\
\text { The Supreme Lord... }\end{array}$ & $\begin{array}{l}\text { Az Istenség Legfelsőbb Személyisége... } \\
\text { The Supreme Personality of Godhead (Itt a kéziratban a } \\
\text { 72-es változat szerepelt, amit a szószedet alapján } \\
\text { javítottak.) }\end{array}$ & A Magasztos Úr... & .... Magasztos Úr... \\
\hline 10.1 & $\begin{array}{l}\text { A Legfelsőbb Úr... } \\
\text { The Supreme Lord... }\end{array}$ & $\begin{array}{l}\text { Az Istenség Legfelsőbb Személyisége... } \\
\text { The Supreme Personality of Godhead (A kéziratból } \\
\text { kimaradt.) }\end{array}$ & A Magasztos Úr... & A Magasztos Úr... \\
\hline 10.19 & $\begin{array}{l}\text { A Magasztos Úr... } \\
\text { The Blessed Lord... }\end{array}$ & $\begin{array}{l}\text { Az Istenség Legfelsőbb Személyisége... } \\
\text { The Supreme Personality of Godhead }\end{array}$ & A Magasztos Úr... & A Magasztos Úr... \\
\hline 11.5 & $\begin{array}{l}\text { Szólt a Magasztos Úr: } \\
\text { 68: The Supreme Personality of Godhead } \\
\text { 72: The Blessed Lord }\end{array}$ & $\begin{array}{l}\text { Az Istenség Legfelsőbb Személyisége... } \\
\text { The Supreme Personality of Godhead }\end{array}$ & A Magasztos Úr... & A Magasztos Úr... \\
\hline 11.32 & $\begin{array}{l}\text {...a Magasztos Úr... } \\
\text { 68: The Supreme Personality of Godhead... } \\
\text { 72: The Blessed Lord... }\end{array}$ & $\begin{array}{l}\text { Az Istenség Legfelsőbb Személyisége... } \\
\text { The Supreme Personality of Godhead }\end{array}$ & A Magasztos Úr... & .... Magasztos Úr... \\
\hline 11.47 & $\begin{array}{l}\text { A Magasztos Úr... } \\
\text { 68: The Supreme Personality of Godhead... } \\
\text { 72: The Blessed Lord... }\end{array}$ & $\begin{array}{l}\text { Az Istenség Legfelsőbb Személyisége... } \\
\text { The Supreme Personality of Godhead... }\end{array}$ & A Magasztos Úr... & A Magasztos Úr... \\
\hline 11.52 & $\begin{array}{l}\text {...a Magasztos Úr... } \\
\text { 68: The Supreme Personality of Godhead } \\
\text { 72: The Blessed Lord... }\end{array}$ & $\begin{array}{l}\text { Az Istenség Legfelsőbb Személyisége... } \\
\text { The Supreme Personality of Godhead... }\end{array}$ & A Magasztos Úr... & A legfelsőbb Úr... \\
\hline 12.2 & $\begin{array}{l}\text { A Magasztos Úr... } \\
\text { 68: The Supreme Personality of Godhead } \\
\text { 72: The Blessed Lord... }\end{array}$ & $\begin{array}{l}\text { Az Istenség Legfelsőbb Személyisége... } \\
\text { The Supreme Personality of Godhead... }\end{array}$ & Az Úr Sri Krishna... & .... Magasztos Úr... \\
\hline
\end{tabular}


Bakaja Zoltán:

Átváltási müveletek a beszélőjelölönek nevezett szanszkrit idéző mondat angol és magyar nyelvü fordításaiban

Argumentum 15 (2019), 755-783

Debreceni Egyetemi Kiadó

DOI: 10.34103/ARGUMENTUM/2019/4

\begin{tabular}{|c|c|c|c|c|}
\hline Versszak & $\begin{array}{l}\text { Dvārakeśa 1. (Bhaktivedanta é. n.) } \\
\text { Bhaktivedanta }(1968,1972)\end{array}$ & $\begin{array}{c}\text { Dvārakeśa }+ \text { ? (Bhaktivedanta 2001, 2014) } \\
\text { Bhaktivedanta }(2015)\end{array}$ & Sebestyén (2000) & $\begin{array}{l}\text { Bakos és Bakos } \\
(2017)\end{array}$ \\
\hline 13.2 & $\begin{array}{l}\text { A Magasztos Úr... } \\
\text { 68: kimaradt; } \\
\text { 72: The Blessed Lord... }\end{array}$ & $\begin{array}{l}\text { Az Istenség Legfelsőbb Személyisége... } \\
\text { The Supreme Personality of Godhead... }\end{array}$ & A Magasztos Úr... & A kegyes Úr... \\
\hline 14.1 & $\begin{array}{l}\text { A Magasztos Úr } \\
\text { 68: The Supreme Personality of Godhead... } \\
\text { 72: The Blessed Lord... }\end{array}$ & $\begin{array}{l}\text { Az Istenség Legfelsőbb Személyisége... } \\
\text { The Supreme Personality of Godhead... }\end{array}$ & A Magasztos Úr... & A kegyes Úr... \\
\hline 14.22 & $\begin{array}{l}\text { A Magasztos Úr... } \\
\text { 68: The Supreme Personality of Godhead... } \\
\text { 72: The Blessed Lord... }\end{array}$ & $\begin{array}{l}\text { Az Istenség Legfelsőbb Személyisége... } \\
\text { The Supreme Personality of Godhead... }\end{array}$ & A Magasztos Úr... & A Magasztos Úr... \\
\hline 15.1 & $\begin{array}{l}\text {... a Magasztos Úr: } \\
\text { 68: The Supreme Lord... } \\
\text { 72: The Blessed Lord... }\end{array}$ & $\begin{array}{l}\text { Az Istenség Legfelsőbb Személyisége... } \\
\text { The Supreme Personality of Godhead... }\end{array}$ & A Magasztos Úr... & A Magasztos Úr... \\
\hline 16.1 & $\begin{array}{l}\text { A Magasztos Úr } \\
\text { 68: The Supreme Personality of Godhead... } \\
\text { 72: The Blessed Lord... }\end{array}$ & $\begin{array}{l}\text { Az Istenség Legfelsőbb Személyisége... } \\
\text { The Supreme Personality of Godhead... }\end{array}$ & A Magasztos Úr... & A legfelsőbb Úr \\
\hline 17.2 & $\begin{array}{l}\text { A Legfelsőbb Úr... } \\
\text { 68: The Supreme Personality of Godhead... } \\
\text { 72: The Supreme Lord... }\end{array}$ & $\begin{array}{l}\text { Az Istenség Legfelsőbb Személyisége... } \\
\text { The Supreme Personality of Godhead... }\end{array}$ & A Magasztos Úr... & - \\
\hline 18.2 & $\begin{array}{l}\text { A Legfelsőbb Úr... } \\
\text { 68: The Supreme Personality of Godhead... } \\
\text { 72: The Supreme Lord... }\end{array}$ & $\begin{array}{l}\text { Az Istenség Legfelsőbb Személyisége... } \\
\text { The Supreme Personality of Godhead... }\end{array}$ & A Magasztos Úr... & ... a Magasztos Úr... \\
\hline
\end{tabular}

2. táblázat. A beszélőjelölő jelzője a magyar forditásokban 
Nehéz eldönteni, hogy a táblázatban szereplö Lord Śrī Krṣna vagy az Úr Krishna esetében a Lord vagy az Úr a jelző vagy az alany fordítása. Én inkább hajlok afelé, hogy a bhagavān célnyelvi megfelelöjéhez tartozik, ám könnyen belelátható a śrī tiszteletteljes megszólítást betöltő funkciója is, különösen akkor, ha a szónak a hindiben használt 'úr, uram' jelentésére gondolunk. Bárhogy is legyen, a śrī változtatás nélküli használata az idegen szóként való átvétel példája, a blessed magasztos-kénti fordítása pedig egyszerü behelyettesítés.

A Bakos házaspár fordításában található kegyes félrefordításnak tünik, a śrī jelentései közt egyetlen általam ismert szótárban sem szerepel, de tekinthetjük a kegyelmes tiszteletteljes megszólítás szótévesztéssel létrejött alakjának is, ez esetben itt is egyszerü behelyettesítéssel van dolgunk, bár a Czuczor-Fogarasi szótár szerint a kegyelmes szó „közép helyen áll a méltóságos, és főméltóságu között”, így nem szerencsés a legfensőbb Istennel kapcsolatban használni.

Amint látható, a supreme-legfelsőbb párost nem azonosítottam a jelölő jelzőjével, mert az véleményem szerint a bhagavān fordításához tartozik. Bhaktivedanta Swami Prabhupāda olyankor is használja, amikor a śrī nem áll a bhagavān elött. A mü második kiadásában a Blessed Lord kifejezés már nem szerepelt, viszont két helyen lefordítatlanul találkozunk a jelzővel $(4.1,6.35)$. A saját, verses fordításomba anélkül illesztettem be a jelzőt, hogy akár azt, akár az alanyt lefordítottam volna (jövevényszókénti átvétel). Ezt nem a szöveg egzotikussá tétele, hanem a ritmika megtartása érdekében tettem: Srí Bhagaván ekképp szólt.

\section{$4 \quad$ A beszélőjelölő alanyának fordítása}

A Bhagavad-gītā beszélőjelölőjének négy alanya lehet: Dhṛtarāșțra, Sañjaya, Arjuna és Kṛ̣ṇa. Közülük az első háromnak a neve változtatás nélkül került át a célnyelvi szövegekbe, illetve a hindi kiadásban ne végződést kap: dhṛtarāṣtrane, sañjayane és arjunane. Az első három szereplő esetében tehát a fordítók az átvételt választják. Kṛ̣nára a jelölő a bhagavān szó használatával utal. A śrī-bhagavān uvāca 28-szor szerepel a könyvben. A szanszkrit bhaga főnév jelentése többek között 'méltóság, fenség, magasztosság', a vat képző pedig a 'birtokolni vmit, rendelkezni vmivel' értelemben használatos. A bhagavān szó a hímnemü bhagavat melléknév egyes szám alanyesetü alakja. A bhagavat szótári jelentése 'dicsőséges, nagy hírü, isteni, imádandó' (Glorious, illustrious, divine, adorable, venerable.) Megértéséhez érdemes elolvasni Bhaktivedanta Swami Prabhupāda magyarázatát:

Persze néha a bhagavān szó bármely hatalmas emberre vagy félistenre is utalhat, és itt minden bizonnyal azért nevezik így Kṛ̣nát, mert ő jelentős személyiség, ám azt is tudnunk kell, hogy az Úr Śrī Krṣṇa maga Isten mindenek fölött álló személye. Ezt az összes kiváló ācārya (lelki tanítómester), például Śan̉karācārya, Rāmānujācārya, Madhvācārya, Nimbārka Svāmī, Śrī Caitanya Mahāprabhu és India védikus tudományának más szaktekintélyei is megerősítik (saját fordítás: Bhaktivedanta 2015: 2-3).

\subsection{A beszélöjelölö alanya az angol fordításokban}

Az alábbi táblázat a bhagavān szó angol fordításait mutatja be. Azokon a helyeken, ahol a jelző beékelődött az alany fordításába, kiemeltem azokat a szavakat, amelyek az alanyt jelzik. Ott, ahol a forrásjegyzékben szereplő tétel nem az angol fordítás készítőjének a nevével kezdődik, zárójelben közöltem a forrásjegyzékben található nevet. 
Bakaja Zoltán:

Átváltási müveletek a beszélőjelölőnek nevezett szanszkrit idézö mondat angol és magyar nyelvü fordításaiban Argumentum 15 (2019), 755-783

Debreceni Egyetemi Kiadó

DOI: 10.34103/ARGUMENTUM/2019/4

\begin{tabular}{|l|l|}
\hline \multicolumn{1}{|c|}{ Fordítók és kiadások } & \multicolumn{1}{c|}{ A bhagavān szó fordítása } \\
\hline Barnett (Macnicol szerk. 1938) & The Lord \\
\hline Besant és Bhagavân (1905) & The Blessed Lord \\
\hline Bhaktivedanta (1968, 1972, 2015) & $\begin{array}{l}\text { Lord Śrī Kṛ̣ṇa; The Blessed Lord; The Supreme Lord; The Supreme } \\
\text { Person; The Supreme Personality; The Supreme Personality of Godhead; } \\
\text { The Personality of Godhead, Lord Srī Kṛ̣̣̣a }\end{array}$ \\
\hline Bhānu (é. n., 2003) & The Lord \\
\hline Bhumipati (Bhaktivinoda 2006) & The Supreme Lord \\
\hline Ithamar (2010) & The blessed Lord \\
\hline Maharishi (1967) & The blessed Lord \\
\hline Marjanovic (Abhinavagupta 2004) & The Lord \\
\hline ? (Nārāyaṇa 2011) & Bhagavān \\
\hline Sagar ( Sridhar 2. URL) & The Supreme Lord; The Lord \\
\hline Swarupananda (Sridhar 2006) & The Supreme Lord; The Lord \\
\hline Wilkins (1785) & Krěěsnă \\
\hline
\end{tabular}

3. táblázat. A bhagavān szó angol forditásai

Láthatjuk, hogy a Bhaktivedanta-fordításban különösen sok variáció szerepel. Ennek az az oka, hogy az első kiadáson több különböző szerkesztő is dolgozott, s a saját részük átnézése közben megváltoztatták a fordító által leginkább használt the Supreme Personality of Godhead alakot. Ahogy azt a 2. táblázatban láthatjuk, a 2., javított kiadásban többnyire már csak ez utóbbi szerepel.

A bhagavān szó fordításának fenti példáiban a fordítónak szinte mindig el kell végeznie egy kötelező átváltási müveletet, a névelö betoldását. Ez csak három esetben nincs így: a Narāyaṇa-kiadásban, ahol a fordító a szanszkrit eredeti idegen szóként való átvételét választotta (itt a beszélőjelölö jelzője előzi meg a szót), Wilkinsnél, aki Kṛ̣̣na személynevét használta, illetve a Bhaktivedanta-fordítás 2. kiadásában ott, ahol a Lord Śrī Kṛṣna alak szerepel $(4.1,6.35)$.

A Fentebbi Bhaktivedanta-idézetből az derült ki, hogy a bhagavān szó átültetésekor a legtöbb fordító konkretizál, vagyis a fenséget és dicsőséget kifejező melléknév általános jelentési tartományát Istenre, illetve Istennek az Arjuna oldalán álló formájára szükíti. A konkretizálás nem minden esetben egyenlő mértékü. A the Lord 'az Úr' (A továbbiakban az egyes angol szavak jelentését az Országh és Magay vezetésével szerkesztett nagyszótár alapján adom meg [2009].) arra utal, hogy a müben szereplő bhagavān nem egyszerüen csak kiváló ö az ura mindennek. Ezt még explicitebben fejezi ki a the Supreme Lord forma, amelyböl megtudhatjuk, hogy ez az Úr felette áll minden más úrnak. A the Supreme Person a Personality of Godhead és a Supreme Personality hasonló jelentéssel bír, de ezekböl azt is megtudhatjuk, hogy az Úr nem a világ felett uralkodó személytelen szellem, hanem személy. A the Supreme Personality of Godhead ('Isten mindenek fölött álló személye') a leginkább explicit kifejezés, amelyben benne foglaltatik az, hogy nem akármilyen úrról, a mindenek fölött álló személyes Istenről van szó. A Lord Śrī Kṛṣna formából azt tudhatjuk meg, hogy ez az Úr Kṛṣna, és a Bhaktivedanta-fordítás a 4. fejezet 1 . versszakában egy még részletesebb le- 
Bakaja Zoltán:

Átváltási müveletek a beszélőjelölönek nevezett szanszkrit idézö mondat angol és magyar nyelvü fordításaiban Argumentum 15 (2019), 755-783

Debreceni Egyetemi Kiadó

DOI: $10.34103 / A R G U M E N T U M / 2019 / 4$

írással is szolgál: The Personality of Godhead, Lord Śrī Kṛṣna. Ezek után már senki sem tévesztheti el: az Arjuna oldalán álló Bhagavān a Kṛ̣nának nevezett Úristen.

Klaudy a lexikai konkretizálást a testrészek, a mozgást jelentő, az idéző, a kezdést kifejező igék és az általános jelentésủ igék esetén írta le (Klaudy 1999: 45-54), itt azonban egy melléknév jelentésének a konkretizálására láttunk példát, amely a különböző mértékű explicitáció eredményeként, lexikai betoldások segítségével jöhetett létre.

\subsection{A beszélójelöló alanya a magyar fordításokban}

A következő táblázatban a bhagavān szónak a vizsgált fordításokban található magyar megfelelöit ismertetem. Ha a fordító nem közvetlenül a szanszkritból dolgozott, akkor zárójelben közöltem a forrásnyelvi fordítás készítőjének a nevét.

\begin{tabular}{|l|l|}
\hline \multicolumn{1}{|c|}{ Fordító } & \multicolumn{1}{|c|}{ Fordítás } \\
\hline Bakaja (2016) & $\begin{array}{l}\text { a fenséges Úr; Az Úr, akinél senki sem gazdagabb, erösebb, híresebb, } \\
\text { szebb, akinél nem tud többet senki, s aki könnyedén lemond } \\
\text { mindenéről; Bhagaván }\end{array}$ \\
\hline Bakos és Bakos (2017) & A[z] Magasztos Úr; Az UUr; A legfelsőbb Úr; A[z] kegyes Úr \\
\hline Baktay (2013) & A Magasztos \\
\hline Dienes (2016) (Maharishi) & Az Áldott Úr \\
\hline Dóka (2003) (Sagar) & A Legfelsőbb Úr; Az Úr \\
\hline $\begin{array}{l}\text { Dvārakeśa, Dāsa és mások (é. n., 2001, } \\
\text { 2014) (Bhaktivedanta) }\end{array}$ & $\begin{array}{l}\text { A Legfelsőbb Személy; A Legfelsőbb Úr; A[z] Magasztos Úr; Az } \\
\text { Istenség Legfelsőbb Szzemélyisége; Bhagavān, a Legfelsőbb Személy }\end{array}$ \\
\hline $\begin{array}{l}\text { Gömöryné (1924) (Besant } \\
\text { Bhagavân) }\end{array}$ & Krisna \\
\hline Kégl (1910) & Az istenség \\
\hline Lakatos (1987) (Vekerdi) & A Magasztos \\
\hline Sebestyén (2000) (?) & $\begin{array}{l}\text { A[z] Magasztos Úr; Bhagawan Krishna; Bhagawan; Az Úr; Az Úr } \\
\text { Krishna; Az Áldott Úr }\end{array}$ \\
\hline Szabó Ágnes (é. n.) (Sivananda) & Az Áldott Úr \\
\hline Szabó Lőrinc (3. URL) (Barnett) & Az Úr \\
\hline Szerdahelyi (1965) (Tóth) & Krisna, A Magasztos \\
\hline Vekerdi (1997) & A Magasztos \\
\hline Virág (2012) (Marjanovic) & Az Úr \\
\hline
\end{tabular}

4. táblázat. A bhagavān szó magyar megfelelöi a vizsgált forditásokban

Mivel Sebestyén forrásszövegét nem ismerem, a fenti táblázatból az általa elvégzett átváltási művelteket nem tudom teljesen biztosan megítélni. A Bhagawan Krishna és a Bhagawan megoldások írásmódjából arra következtetek, hogy itt az idegen szóként való átvételt választotta, az angol forrásszöveg írásmódja alapján. Az Az Áldott Úr formát csak a 8.3. versszakban használja, és nem derül ki, hogy a forrásnyelvben csak itt szerepelt a the Blessed Lord, vagy máshol is, illetve itt állt valami más és a the Blessed Lord megfelelöjéül választotta az $A$ 
Magasztos Úr-t. A legtöbb esetben valószínűleg az egyszerű behelyettesítést alkalmazta, illetve az Az Úr Krishna esetében keveredik a fordításban az egyszerü behelyettesítés és az idegen szóként való átvétel.

A szanszkritból fordító Baktay és Vekerdi automatikusan végrehajtotta a névelö betoldását, majd behelyettesítette a bhagavān-t a magasztossal. Kégl szintén betoldotta a névelöt, és az általános jelentésü bhagavān szót az istenség magyar megfelelővel konkretizálta. Gömöryné szintén konkretizált, amikor Besant és Bhagavân The Blessed Lord-ja helyett a Krisna-t használta. Ez a konkretizálás a névelő kihagyásával és a Krisna jövevényszókénti átvételével valósulhatott meg. Intralingvális átvételt láthatunk pl. Lakatos esetében, aki szó szerint vette át az a Magasztos-t Vekerdi nyersfordításából.

Érdekes, hogy miért választotta Dvārakeśa az Az Istenség Legfelsőbb Személyisége szólt megoldást a 4.1. versszakban, amikor az angolban a The Blessed Lord said áll. Talán véletlen elírás lehet, amelynek az a forrása, hogy a szószedetben az angol is a The Supreme Personality of Godhead said formát alkalmazza és a szerző a magyarázatokban is ezt használja a legtöbbször a bhagavān angol megfelelöjeként. Ahhoz, hogy a The Supreme Personality of Godhead said-ből Az Istenség Legfelsőbb Személyisége szólt legyen, grammatikai áthelyezés szükséges. Az angol birtokos szerkezet előtt álló minőségjelző a magyarban beékelődik a birtokos szerkezet tagjai közé.

Az én prózai fordításomban egy esetben betoldással konkretizáltam az alanyt, ekkor a fenséges-nek fordított bhagavān után az Úr szót is a fordításához csatoltam. A második alkalommal a szó fordítása jelentős terjedelmű explicitációt tartalmaz. Itt előrevettem a jelentést önmagában is konkretizáló úr szót, s aztán a Bhaktivedanta-kiadás egy hivatkozása alapján (2015 2.2) sok-sok lexikai egység betoldásával fejtettem ki részletesen, hogy mi az a hat fenséges tulajdonság, amelyet birtokolni kell ahhoz, hogy valakit bhagavān-nak nevezzenek. Ezzel a szó jelentését még konkrétabbá, még kézzelfoghatóbbá tettem. A verses fordításom jövevényszóként (Bhagaván) veszi át a forrásnyelvi kifejezést.

Az itt nem említett többi fordító az angol szöveg magyarítása során az egyszerü behelyettesítés eszközével élt.

\section{$5 \quad$ A beszélőjelölő igéjének fordítása}

\subsection{Példák a beszélöjelölő igéjének angol fordítására}

Az 5. és 7. táblázatban azt mutatom be, hogyan konkretizálták az egyes angol és magyar fordítások készítői a beszélőjelölő igéjét. Az 5. táblázat fejlécének első sorában a fordító neve áll. Ha az angol fordítás nem az eredeti szanszkritból, hanem annak hindi vagy bengáli fordításából készült, akkor zárójelben az eredeti fordító neve olvasható. Ugyanannak a könyvnek a különbözö kiadásait ' $/$ ' jellel választottam el. A 6. oszlop kérdőjele arra utal, hogy a könyvben nem nevezik meg az angol fordítót. A '-' jelet akkor használtam, amikor az adott versszakban hiányzott a jelölö, vagy kihagyták belőle az igét. Félkövér betüvel szedtem azokat a helyeket, ahol a fordító nem az általa leggyakrabban használt igei alakot alkalmazta az adott versszakban, valamint kiegészítette vagy konkretizálta a jelölő igéjét. 
Bakaja Zoltán:

Átváltási müveletek a beszélöjelölőnek nevezett szanszkrit idéző mondat angol és magyar nyelvü fordításaiban

Argumentum 15 (2019), 755-783

Debreceni Egyetemi Kiadó

DOI: 10.34103/ARGUMENTUM/2019/4

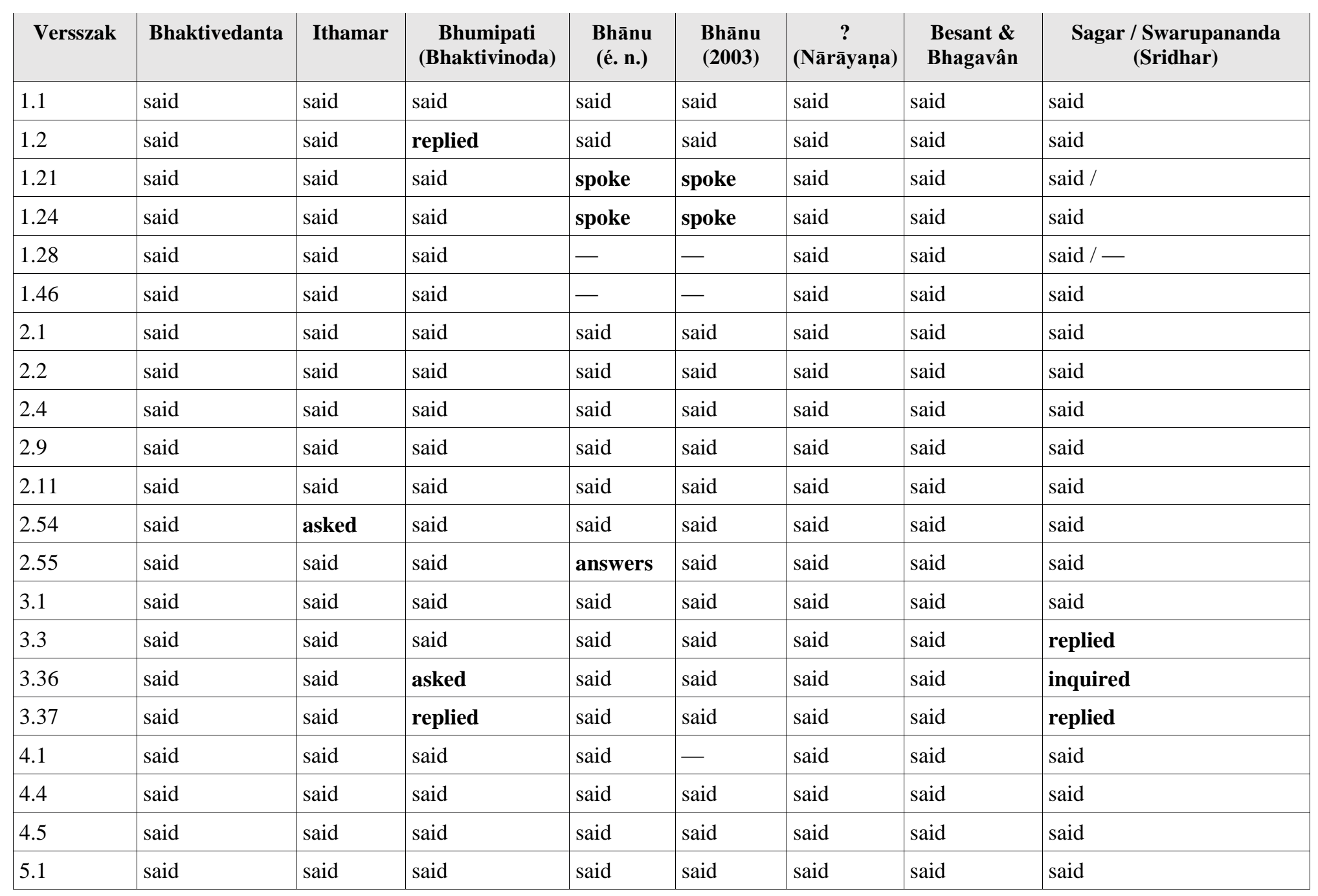


Bakaja Zoltán:

Átváltási müveletek a beszélőjelölőnek nevezett szanszkrit idéző mondat angol és magyar nyelvü fordításaiban

Argumentum 15 (2019), 755-783

Debreceni Egyetemi Kiadó

DOI: 10.34103/ARGUMENTUM/2019/4

\begin{tabular}{|c|c|c|c|c|c|c|c|c|}
\hline Versszak & Bhaktivedanta & Ithamar & $\begin{array}{c}\text { Bhumipati } \\
\text { (Bhaktivinoda) }\end{array}$ & $\begin{array}{l}\text { Bhānu } \\
\text { (é. n.) }\end{array}$ & $\begin{array}{l}\text { Bhānu } \\
\text { (2003) }\end{array}$ & $\begin{array}{c}? \\
\text { (Nārāyaṇa) }\end{array}$ & $\begin{array}{l}\text { Besant \& } \\
\text { Bhagavân }\end{array}$ & $\begin{array}{c}\text { Sagar / Swarupananda } \\
\text { (Sridhar) }\end{array}$ \\
\hline 5.2 & said / replied & said & said & said & said & said & said & said \\
\hline 6.33 & said & said & said & - & - & said & said & said \\
\hline 6.35 & said & said & said & said & said & said & said & said \\
\hline 6.40 & said & said & said & said & - & said & said & said \\
\hline 7.1 & said & said & said & said & said & said & said & said \\
\hline 8.1 & inquired & said & said & said & said & inquired & said & inquired \\
\hline 8.3 & replied / said & said & said & said & said & said & said & said / spoke thus \\
\hline 10.19 & said & said & said & - & said & said & said & said \\
\hline 11.1 & said & said & said & said & said & said & said & said \\
\hline 11.5 & said & said & said & said & said & said & - & said \\
\hline 11.9 & said & said & said & said & said & said & said & said \\
\hline 11.15 & said & said & - & said & said & said & said & said \\
\hline 11.32 & said & said & said & said & said & said & said & said \\
\hline 11.35 & said & said & said & said & said & said & said & said \\
\hline 11.36 & - / said & said & said & said & said & said & said & said \\
\hline
\end{tabular}


Bakaja Zoltán:

Átváltási müveletek a beszélőjelölőnek nevezett szanszkrit idézö mondat angol és magyar nyelvü forditásaiban

Argumentum 15 (2019), 755-783

Debreceni Egyetemi Kiadó

DOI: 10.34103/ARGUMENTUM/2019/4

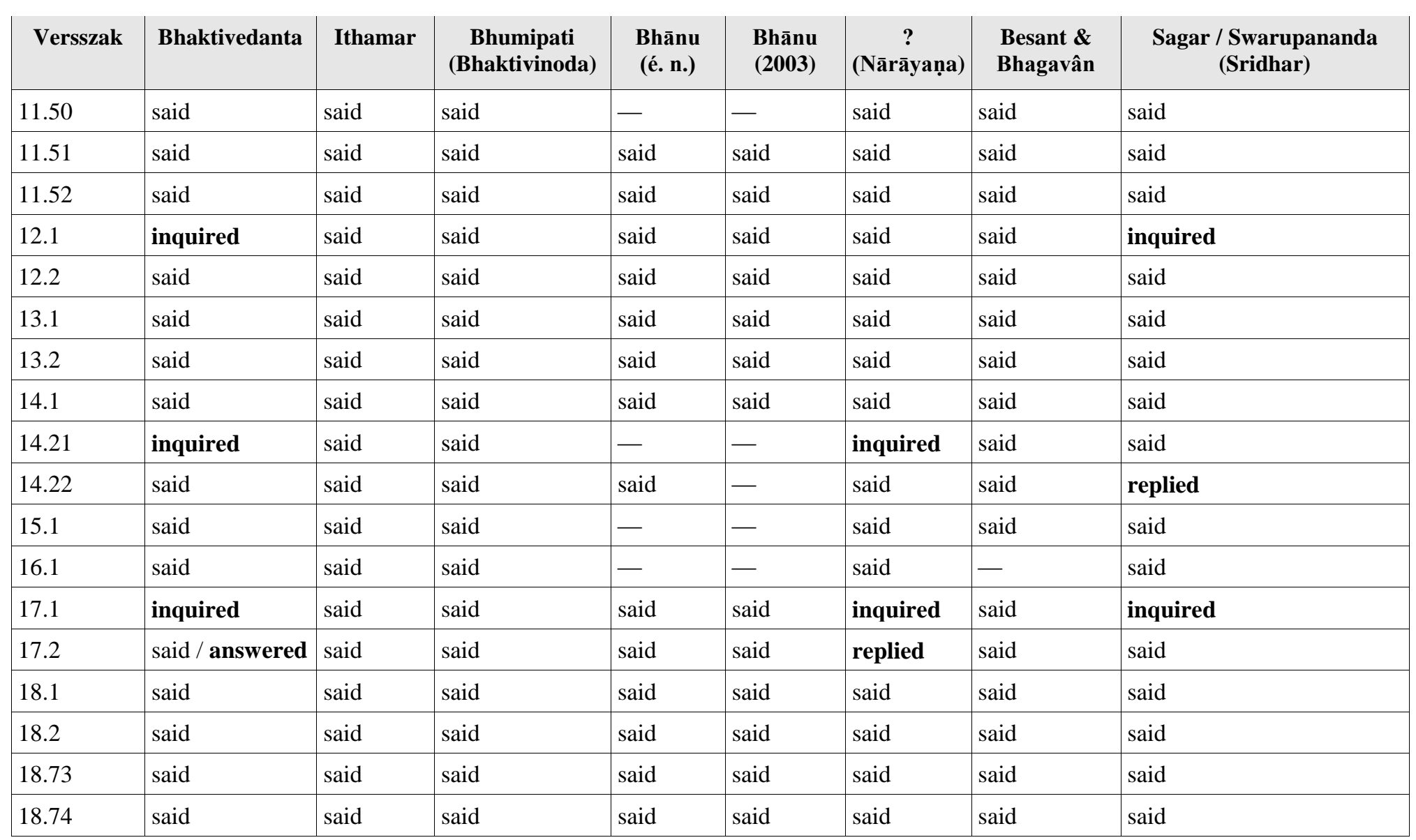

5. táblázat. A beszélőjelölő igéjének angol forditásai 
A táblázatot összefoglalva azt mondhatjuk, hogy a fordításokban az $u v a ̄ c a$ megfelelőjeként legtöbbször a said ('mondta') áll (egyszerü behelyettesítés). A vizsgált müvek alapján tehát úgy tünik, hogy az uvāca angolra való átültetésében létezik egy fordítói hagyomány, amely a said használatát részesíti előnyben. Egyedül Bhānu Swāmīnál találunk ettől eltérő, általános jelentéssel rendelkező, beszédet kifejező igét, és nála is csak két versszakban. A spoke ('beszélt') mindkét fordításában ugyanott található meg, az 1. fejezet 21. és 24. versszakában. Ez az azonosság nem meglepő, mert az általa készített két verzió csak csekély mértékben tér el egymástól. A spoke-ot egyszer Svarupananda is használja (8.3), de ő a thus határozószóval is kiegészíti ('így/ekképpen szólt/beszélt'). Swarupananda tehát betoldást is alkalmaz. Ezt a megoldást nem tartom túl szerencsésnek, mert a megszólalás módjára vagy a következő szövegrész tartalmára irányítja a figyelmet, holott a jelölö, nevéhez hủen, pusztán csak a beszélő kilétét jelzi, és nem az őt követő dolgok jellegére vagy tartalmára koncentrál.

Klaudy kétfajta betoldást különböztet meg: lexikait (1999: 100-112) és grammatikait (1999: 213-224). Szerinte a lexikai betoldásokat az olvasók háttérismereteinek hiánya, a grammatikaiakat pedig a nyelvek közötti szintaktikai különbségek indokolják. A grammatikai betoldásokat említve a nyomatékosító elemek betoldásáról is ír, amelyek szövegszervezö elemekként szolgálnak, vagy pedig a mondat hangsúlyos részeit jelölik velük a fordítók. Ahogy korábban említettem, itt az előreutalást ellentétesnek tartom a beszélőjelölő természetével, ezért úgy tünik, hogy nem valamilyen tudatos fordítói stratégia része. Ezzel kapcsolatban felmerülhet az emberben, hogy egyszerüen csak így tetszett neki jobban ez a rész, azaz a fordító nemcsak az információátadás vagy a szövegszervezés kényszere, hanem valamilyen belső stilisztikai igénynek való megfelelni vágyás hatására is végezhet betoldást.

A fordítók a következő négy kifejezés használatával konkretizálják a jelölő igéjét: replied ('válaszolt, felelt'), asked ('kérdezte, megkérdezte'), answers ('válaszol, megválaszolja'), inquired ('kérdezte, megkérdezte, érdeklödött'). Két olyan versszak van $(8.1,17.1)$, ahol négy fordító is konkretizálja az igét, s ezt mindannyian ugyanazzal a szóval teszik. E fordítások készítői (Bhaktivedanta, Nārāyaṇa könyvének fordítója és Sagar, valamint Swarupananda) mind azonos felekezethez tartoznak, így felmerül az emberben a kérdés, hogy vajon véletlen-e az egyezés, vagy valamilyen korábbi forrásmunka követése az oka. Ennek megítélését nehezíti, hogy ezek közül csak a Bhaktivedanta-fordítás készült a szanszkrit eredetiből, Nārāyāṇa könyvének angol kiadása a szerző hindi, Sridharé pedig az ő bengáli nyelvü könyvéből lett elkészítve. Sajnos sem Sridhar, sem Bhaktivinoda bengáli müve sincs a birtokomban, így azt nem tudom megvizsgálni, hogy a szanszkrit bengálira történő lefordítása során mi történik a beszélőjelölővel.

Logikusnak tünik, hogy ha összehasonlítjuk Sridhar Swami könyvének két angol kiadását, abból talán messzemenőbb következtetéseket is le tudunk vonni. Nekem a könyv első angol nyelvü kiadása csak egy hiányos, pdf-ben letöltött változatban van meg, de szerencsére az interneten megtalálható a két angol szöveg összehasonlítható verziója (4. URL). Ott az első kiadás pontos könyvészeti adatait sajnos nem találtam meg. A 6. táblázat második sorában a fordítók neve szerepel. A magyar kiadás igéit is beszúrtam, így mind a három fordítás összevethetö. Ahol a két angol kiadás különbözött, ott a ' $/$ ' jel bal oldalán az elsőben, a jobbon pedig a másodikban szereplő megoldás olvasható. Azokat a szavakat jelöltem félkövérrel, amelyek eltérnek a fordító által leggyakrabban használt formától. A '_- jel a jelölő hiányára utal, ami inkább tünik sajtóhibának, mintsem tudatos választásnak. 
Bakaja Zoltán:

Átváltási müveletek a beszélőjelölönek nevezett szanszkrit idézö mondat angol és magyar nyelvü fordításaiban Argumentum 15 (2019), 755-783

Debreceni Egyetemi Kiadó

DOI: 10.34103/ARGUMENTUM/2019/4

\begin{tabular}{|c|c|c|}
\hline \multicolumn{3}{|c|}{$\begin{array}{c}\text { Sridhar Dev-Goswami } \\
\text { Srīmad Bhagavd-gītā: The Hidden Treasure of the } \\
\text { Sweet Absolute }\end{array}$} \\
\hline Versszak & $\begin{array}{c}\text { Sagar / } \\
\text { Swarupananda }\end{array}$ & Dóka \\
\hline 1.1 & said & így szólt \\
\hline 1.2 & said & válaszolt \\
\hline 1.21 & said / — & így szólt \\
\hline 1.24 & said & ekképp folytatta \\
\hline 1.28 & said / — & így szólt \\
\hline 1.46 & said & így szólt \\
\hline 2.1 & said & folytatta \\
\hline 2.2 & said & így szólt \\
\hline 2.4 & said & ekképp válaszolt \\
\hline 2.9 & said & így szólt \\
\hline 2.11 & said & így szólt \\
\hline 2.54 & said & \begin{tabular}{|l|} 
ekképp \\
érdeklódött
\end{tabular} \\
\hline 2.55 & said & ekképp válaszolt \\
\hline 3.1 & said & így szólt \\
\hline 3.3 & replied & \begin{tabular}{|l|} 
ekképpen \\
válaszolt
\end{tabular} \\
\hline 3.36 & inquired & érdeklódött \\
\hline 3.37 & replied & válaszolt \\
\hline 4.1 & said & így szólt \\
\hline 4.4 & said & így szólt \\
\hline 4.5 & said & Így szólt \\
\hline 5.1 & said & így kérdezett \\
\hline 5.2 & said & válaszolt \\
\hline 6.1 & said & szólt \\
\hline 6.33 & said & így szólt \\
\hline 6.35 & said & szólt \\
\hline 6.37 & said & így kérdezett \\
\hline 6.40 & said & válaszolt \\
\hline 7.1 & said & szólt \\
\hline 8.1 & inquired & \begin{tabular}{|l|} 
ekképp \\
tudakozódott
\end{tabular} \\
\hline 8.3 & said / spoke thus & szólt \\
\hline
\end{tabular}

\begin{tabular}{|c|c|c|}
\hline \multicolumn{3}{|c|}{$\begin{array}{l}\text { Sridhar Dev-Goswami } \\
\text { Śrimad Bhagavd-gītā: The Hidden Treasure of the } \\
\text { Sweet Absolute }\end{array}$} \\
\hline Versszak & $\begin{array}{c}\text { Sagar / } \\
\text { Swarupananda }\end{array}$ & Dóka \\
\hline 9.1 & said & Szólt \\
\hline 10.1 & said & Szólt \\
\hline 10.12 & said & így szólt \\
\hline 10.19 & said & szólt \\
\hline 11.1 & said & szólt \\
\hline 11.5 & said & szólt \\
\hline 11.9 & said & szólt \\
\hline 11.15 & said & így szólt \\
\hline 11.32 & said & szólt \\
\hline 11.35 & said & szólt \\
\hline 11.36 & said & így szólt \\
\hline 11.47 & said & szólt \\
\hline 11.50 & said & szólt \\
\hline 11.51 & said & szólt \\
\hline 11.52 & said & Szólt \\
\hline 12.1 & inquired & érdeklődött \\
\hline 12.2 & said & szólt \\
\hline 13.1 & said & szólt \\
\hline 13.2 & said & szólt \\
\hline 14.1 & said & szólt \\
\hline 14.21 & said & kérdezett \\
\hline 14.22 & replied & válaszolt \\
\hline 15.1 & said & Szólt \\
\hline 16.1 & said & szólt \\
\hline 17.1 & inquired & tudakozódott \\
\hline 17.2 & said & válaszolt \\
\hline 18.1 & said & szólt \\
\hline 18.2 & said & szólt \\
\hline 18.73 & said & szólt \\
\hline 18.74 & said & szólt \\
\hline
\end{tabular}


Noha, ahogy az a táblázatból is látszik, a két angol kiadás között mindössze egyetlen különbség van a jelölő igéjének a fordításában, mégse merném azt állítani, hogy ennek az oka a bengáli eredetiben keresendő. A két szöveget összehasonlítva azt láthatjuk, hogy sok átfedés van közöttük, így elképzelhető, hogy a második kiadás készítője egyszerüen csak az elődjére épített, és megtartotta, amit megtarthatónak gondolt. Nārāyaṇa Svāmī hindi fordítása nem konkretizálja az igét, a dhṛtarāștrane kahā, sañjayane kahā, arjunane kahā, és a srībhagavānne kahā található meg benne (kahāa - 'mondta'). A fentiek fényében a konkretizálás egybeesése inkább tünik a véletlen müvének, mintsem egy előző minta követésének. Ha lehet valamilyen minta, az inkább a Bhaktivedanta-fordítás, mert az már létezett, amikor a másik három angol fordítás készült.

Az 5. táblázatban nincs ott minden olyan angol kiadás, amelyet végignéztem. A Macnicol szerkesztette Hindu Scriptures (1938) L. D. Barnett fordítását tartalmazza (225-287). Ebben ő a beszélőjelölő igéjének a visszaadására mindenütt a spake-et használja. A kiadásban kimaradt a 2. fejezet 9. versszaka előtti jelölő, valamint a 13. fejezet Arjuna kérdését tartalmazó 1. versszaka, amely előtt szintén a jelölő állna. Wilkins (1785) az 1 . fejezet 1 . versszakában a said-et a következőben pedig a replied-ot használja, azután azonban végig kihagyja az igét, csak a beszélők nevét tünteti fel. Van néhány olyan hely, ahol a beszélőjelölő teljesen kimarad a fordításból $(1.24,1.46,2.1,2.9)$. Marjanovic és Sivananda - ahogy Maharishi is az általa lefordított hat fejezetben - mindenütt a said-et használja. A versszakok eltérő számozása miatt a két versszak előtt nem áll jelölö $(1.21,1.28)$.

Klaudy a fordítás során születő hiányos mondatok keletkezését (1999: 234-235) a grammatikai kihagyás kategóriájába sorolja be. A beszélőjelölő kihagyással történő fordítása esetében az idéző mondat egyetlen szóból áll, amely a beszélő személyét mutatja meg. Ennél nem is kell több. A korabeli szanszkrit szövegek esetében ezt nehéz lett volna az uvāca vagy legalább egy iti ('így') nélkül megoldani, mert helytakarékossági okokból mindent folyamatosan írtak, kettőspont pedig nincs a devanāgari írásban (az iti töltheti be ezt a funkciót). A latin betüs írás központozásának a segítségével vagy a modern tipográfia alkalmazásával az alany megjelölése teljes mértékben elég a beszélő kilétének meghatározására.

A megvizsgált angol nyelvü kiadások fordítói a beszélőjelölő átültetésekor az egyszerü behelyettesítés mellet három további átváltási müveletet alkalmaznak: a konkretizálást, a kihagyást és a betoldást. Érdekes módon ezek egyike sem tünik elöre eltervezett stratégia megvalósításának. Wilkins 1. és a 2. versszakit kivéve mindenhol kihagyja az igét. A Swarupanada által a 8. fejezet 3. versszakának jelölöjében alkalmazott betoldásnak sincs olyan szerepe, ami a betoldás szükségességét indokolná. Akkor sem látunk következetes megoldásokat, amikor a konkretizálás a megszólalás kérdés, illetve válasz voltának megmutatására irányul. Az asked vagy inquired ('kérdezte, érdeklödött') igét tartalmazó jelölöt csak elvétve követi olyan, amelyben a replied vagy az answered ('válaszolt, felelt') szerepel. Mivel a konkretizálást tartalmazó kiadásokban vannak versszakok közé szúrt magyarázatok is - sokszor a versszakok szanszkrit eredetijével és szavankénti fordításával együtt - a konkretizálás stilisztikai hatása nem tud érvényesülni a könyv teljes tartalmának elolvasása során. 


\subsection{A beszélöjelölö igéje a magyar fordításokban}

A 7. táblázat a beszélőjelölő igéjének magyar fordításait tartalmazza. Azok, amelyek nem szerepelnek e táblázatban, mindig ugyanazt az igét használják az eredeti idéző ige fordításakor. A következő felsorolás e szerzők nevét s az általuk használt igét vagy szerkezetet tartalmazza:

Bakaja verses fordítása (2016): ekképp szólt.

Baktay (2013): következetesen kihagyja az igét, a jelölöben csak a beszélő neve szerepel.

Dienes (2016): szólt.

Kégl (1910): így szólt.

Szabó Ágnes (é. n.) szól.

Szabó Lőrinc (5. URL): szólt.

Szerdahelyi (1965): szólt.

Vekerdi (1997): szólt.

Virág (2012): szólt.

A 7. táblázat fejlécében először a fordító neve szerepel, azt követi, hogy kinek a fordításából dolgozott. A Bhaktivedanta-fordítás három magyar kiadása közötti eltérést a '/' jel használatával mutatom meg. Amennyiben ez csak egyszer szerepel, akkor a jel bal oldalán az 1., a jobbon pedig a 2. és 3. kiadás megoldása található. Azokon a helyeken, ahol a 2. kiadás eltér a 3-tól, mindhárom verzió szerepel, s a 2. kiadásban található szó középen van. Azokat az alakokat szedtem vastaggal, amelyek eltérnek az adott fordító által a leggyakrabban használttól. Ez alól kivételt képeznek azok az esetek, amelyekben a szokványostól való eltérésnek az oka az angol szöveghez való igazodás. Dölttel szedtem azokat az eseteket, amelyek nem az alany után, hanem elé kerültek. A '—_ jel az ige vagy a teljes jelölő hiányára utal. 
Bakaja Zoltán:

Átváltási müveletek a beszélőjelölőnek nevezett szanszkrit idézö mondat angol és magyar nyelvü forditásaiban

Argumentum 15 (2019), 755-783

Debreceni Egyetemi Kiadó

DOI: 10.34103/ARGUMENTUM/2019/4

\begin{tabular}{|c|c|c|c|c|c|c|c|}
\hline Versszak & $\begin{array}{c}\text { Gömöryné (Besant } \\
\text { és Bhagavân) }\end{array}$ & $\begin{array}{c}\text { Lakatos } \\
\text { (Vekerdi) }\end{array}$ & Dvārakeśa / ? / ? (Bhaktivedanta) & Sebestyén (?) & Dóka (Sagar) & $\begin{array}{l}\text { Bakaja prózai } \\
\text { fordítása }\end{array}$ & $\begin{array}{c}\text { Bakos és } \\
\text { Bakos }\end{array}$ \\
\hline 1.1 & szól & szólt & így szólt / így szólt & így szólt & így szólt & & szólott \\
\hline 1.2 & szól & szólt & így felelt / így szólt & így felelt & válaszolt & & felelt \\
\hline 1.21 & - & szólt & szólt / így szólt & így szólt & így szólt & & így szólt \\
\hline 1.24 & szól & szólt & folytatta / így szólt & így szólt & ekképp folytatta & & szólott \\
\hline 1.28 & szól & szólt & szólt / szólt / így szólt & így szólt & így szólt & & szólt \\
\hline 1.46 & szól & szólt & mondta & így szólt & így szólt & & szólott \\
\hline 2.1 & szól & - & mondta & így szólt & folytatta & tovább mesélt & szólt \\
\hline 2.2 & - & szólt & szólt / így szólt & így beszélt & így szólt & - & szólott \\
\hline 2.4 & szól & szólt & szólt / így szólt & így szólt & ekképp válaszolt & felelte & szólt \\
\hline 2.9 & szól & szólt & folytatta / szólt & így szólt & így szólt & folytatta & folytatta \\
\hline 2.11 & - & szólt & szólt / így szólt & szólt & így szólt & mondta & szólt \\
\hline 2.54 & szól & szólt & kérdezte / így szólt & így szólt & ekképp érdeklődött & kérdezte & így kérdezett \\
\hline 2.55 & szól & szólt & válaszolt / így szólt & felelt & ekképp válaszolt & így válaszolt & így válaszolt \\
\hline 3.1 & szól & szólt & szólt / így szólt & kérdi & így szólt & & így szólt \\
\hline 3.3 & szól & szólt & szólt / így szólt & válaszolt & ekképpen válaszolt & & válaszolt \\
\hline 3.36 & szól & szólt & szólt / így szólt & szólt & érdeklődött & & így kérdezett \\
\hline 3.37 & - & szólt & így válaszolt / így szólt & válaszolt & válaszolt & & válaszolt \\
\hline 4.1 & - & szólt & szólt / így szólt & szólt & így szólt & & szólott \\
\hline 4.4 & szól & szólt & így kérdezett / így szólt & így szólt & így szólt & & így szólt \\
\hline 4.5 & - & szólt & így válaszolt & válaszolt & így szólt & & így válaszolt \\
\hline 5.1 & szól & szólt & szólt / így szólt & így szólt & így kérdezett & & így szólt \\
\hline
\end{tabular}


Bakaja Zoltán:

Átváltási müveletek a beszélőjelölönek nevezett szanszkrit idézö mondat angol és magyar nyelvü fordításaiban

Argumentum 15 (2019), 755-783

Debreceni Egyetemi Kiadó

DOI: 10.34103/ARGUMENTUM/2019/4

\begin{tabular}{|c|c|c|c|c|c|c|c|}
\hline Versszak & $\begin{array}{c}\text { Gömöryné (Besant } \\
\text { és Bhagavân) }\end{array}$ & $\begin{array}{c}\text { Lakatos } \\
\text { (Vekerdi) }\end{array}$ & Dvārakeśa / ? / ? (Bhaktivedanta) & Sebestyén (?) & Dóka (Sagar) & $\begin{array}{c}\text { Bakaja prózai } \\
\text { fordítása }\end{array}$ & $\begin{array}{c}\text { Bakos és } \\
\text { Bakos }\end{array}$ \\
\hline 5.2 & szól & szólt & így válaszolt & felelt & válaszolt & & így válaszolt \\
\hline 6.1 & szól & szólt & szólt / így szólt & szólt & szólt & & szólott \\
\hline 6.33 & szól & szólt & szólt / így szólt & szólt & így szólt & & - \\
\hline 6.35 & szól & szólt & szólt / így szólt & válaszolt & szólt & & válaszolt \\
\hline 6.37 & szól & szólt & kérdezett / így szólt & kérdi & így kérdezett & & így kérdezett \\
\hline 6.40 & szól & szólt & így válaszolt & szólt & válaszolt & & szólt \\
\hline 7.1 & szól & szólt & szólt / így szólt & szólt & szólt & & szólott \\
\hline 8.1 & szól & szólt & így kérdezett & szólt & ekképp tudakozódott & & így kérdezett \\
\hline 8.3 & szól & szólt & ekképpen válaszolt / így szólt & szólt & szólt & & válaszolt \\
\hline 9.1 & szól & szólt & szólt / így szólt & szólt & szólt & & szólt \\
\hline 10.1 & szól & szólt & szólt / így szólt & szólt & szólt & & szólt \\
\hline 10.12 & Szól & szólt & szólott / így szólt & szólt & így szólt & & szólt \\
\hline 10.19 & Szól & szólt & szólott / így szólt & szólt & szólt & & szólt \\
\hline 11.1 & szól & szólt & szólott / így szólt & szólt & szólt & & így szólt \\
\hline 11.5 & szól & szólt & szólt / így szólt & szólt & szólt & & szólt \\
\hline 11.9 & - & szólt & szólt / mondta & így szólt & szólt & & így beszélt \\
\hline 11.15 & szól & szólt & szólt / szólt & így szólította meg & így szólt & & szólott \\
\hline 11.32 & szól & szólt & szólt / így szólt & szólt & szólt & & szólt \\
\hline 11.35 & Szól & szólt & így szólt / így szólt & szólt & szólt & & így szólt \\
\hline 11.36 & - & szólt & — / így szólt & így szólt & így szólt & & szólott \\
\hline 11.47 & szól & szólt & szólt / így szólt & szólt & szólt & & szólt \\
\hline
\end{tabular}


Bakaja Zoltán:

Átváltási müveletek a beszélőjelölőnek nevezett szanszkrit idéző mondat angol és magyar nyelvü fordításaiban

Argumentum 15 (2019), 755-783

Debreceni Egyetemi Kiadó

DOI: 10.34103/ARGUMENTUM/2019/4

\begin{tabular}{|c|c|c|c|c|c|c|c|}
\hline Versszak & $\begin{array}{c}\text { Gömöryné (Besant } \\
\text { és Bhagavân) }\end{array}$ & $\begin{array}{c}\text { Lakatos } \\
\text { (Vekerdi) }\end{array}$ & Dvārakeśa / ? / ? (Bhaktivedanta) & Sebestyén (?) & Dóka (Sagar) & $\begin{array}{l}\text { Bakaja prózai } \\
\text { fordítása }\end{array}$ & $\begin{array}{l}\text { Bakos és } \\
\text { Bakos }\end{array}$ \\
\hline 11.50 & szól & szólt & e szavakkal fordult & szólt & szólt & & így szólt \\
\hline 11.51 & szól & szólt & így szólt / így szólt & szólt & szólt & & így szólt \\
\hline 11.52 & szól & szólt & szólt / így szólt & szólt & szólt & & így szólt \\
\hline 12.1 & szól & szólt & így kérdezett & kérdi & érdeklődött & & szólott \\
\hline 12.2 & szól & szólt & szólt / így szólt & válaszolt & szólt & & szólt \\
\hline 13.1 & szól & $\begin{array}{l}\text { kimaradt } \\
\text { versszak }\end{array}$ & szólt / szólt & kérdi & szólt & & szólt \\
\hline 13.2 & szól & szólt & így válaszolt & szólt & szólt & & szólott \\
\hline 14.1 & Szól & szólt & szólt / így szólt & szólt & szólt & & szólt \\
\hline 14.21 & szól & szólt & kérdezett / így kérdezett & kérdi & kérdezett & & szólt \\
\hline 14.22 & szól & szólt & így válaszolt & szólt & válaszolt & & így válaszolt \\
\hline 15.1 & Szól & szólt & szólt / így szólt & szólt & szólt & & szólott \\
\hline 16.1 & Szól & szólt & szólott / így szólt & szólt & szólt & & így szólt \\
\hline 17.1 & szól & szólt & kérdezett / így kérdezett & szólt & tudakozódott & & így kérdezett \\
\hline 17.2 & szól & szólt & szólott / így szólt & szólt & válaszolt & & - \\
\hline 18.1 & szól & szólt & szólt / így szólt & szólt & szólt & & így szólt \\
\hline 18.2 & Szól & szólt & szólott / így szólt & szólt & szólt & & szólt \\
\hline 18.73 & Szól & szólt & szólt / szólt / így szólt & így felelt & szólt & & szólt \\
\hline 18.74 & Szól & szólt & szólt / szólt & szólt & szólt & & szólt \\
\hline
\end{tabular}

7. táblázat. A beszélőjelölö igéjének magyar forditásai 
Láthatjuk, hogy a magyar fordítások elemzésekor valóban gazdagabb igekészletet találunk, mint amilyet az angol fordítások használtak. A magyar hagyomány a jelölő igéjét leggyakrabban a szólt alakkal helyettesíti be. Több más, egyszerü behelyettesítéssel kapott formát is találtam, ezek a szólott és a mondta. Mivel néha az angol fordítók is konkretizálták az igét, ezért az adott kiadás magyar fordításában olykor egyszerü behelyettesítésnek számít a kérdezett, tudakozódott, válaszolt és érdeklödött. A leggyakrabban elöforduló igéhez kapcsolódó határozószó betoldásával (nyomatékosító elem betoldása) keletkezett a sokszor megjelenő igy szólt és az ekképp szólt forma. Néha a betoldás a szanszkrit ige konkretizált megfelelöjéhez társult, ebböl lett az ekképpen válaszolt, ekképp tudakozódott, így válaszolt és így kérdezett. Ezek legtöbbször az angolból fordított kiadásokban bukkannak fel, ilyenkor a magyar fordítás az ige esetében nem konkretizálást, hanem egyszerü behelyettesítést alkalmaz. Ahogy azt már fentebb említettem, Baktay a kihagyást választotta, egyszer sem használ igét a jelölőben. Fordításában az igét a kettőspont helyettesíti, amely jelzi, hogy a megnevezett személy szavait olvassuk. Néha Gömöryné is kihagyja az igét, van, hogy az egész jelölő elmarad. A lexikai konkretizálásra a következő példákat találhatjuk: érdeklödött, felelt, felelte, folytatta, kérdezte, kérdi, tudakozódott, válaszolt. (Sebestyén fordításának az angol eredetijéhez nem jutottam hozzá, azt feltételeztem, hogy az angolban mindenütt a said áll, és ennek megfelelően értékeltem az átváltási műveleteit. Ha az angolban itt egy múlt idejü, kérdést kifejező ige áll, akkor az általa alkalmazott művelet az ige idejének a megváltoztatása volt, jelenidejű, kérdést kifejező ige esetén pedig egyszerü behelyettesítés.) Van néhány olyan eset, amikor a grammatikai betoldás és a lexikai konkretizálás egyaránt jelen van: ekképp érdeklödött, ekképp folytatta, ekképp válaszolt, e szavakkal fordult, igy felelt, igy kérdezett, igy szólitotta meg, igy válaszolt, tovább mesélt. Bár a beszélőjelölő igéje múlt idejü, Gömöryné és Szabó Ágnes (aki jelzi, hogy helyenként Gömöryné szövegére támaszkodik) a beszélőjelölöben az ige formájának a megváltoztatását választja, és a jelen idejü szól-t használja. A fordítás ezzel azt a hatást kelti, mintha a párbeszédet egy színpadon néznénk, s ez Gömöryné színésznői múltjára való tekintettel nem is meglepö.

Csakúgy, mint a Sridhar-kiadás esetében, a Bhaktivedanta-fordításról is készítettem egy olyan táblázatot, amelyen egyszerre láthatóak a mü angol és magyar kiadásának megoldásai. Az 1. angol kiadás 1968-ban jelent meg, ez azonban a könyvnek csak egy hozzávetőlegesen 400 oldallal megrövidített változata volt. A teljes kiadás 1972-ben látott napvilágot. Ez föleg abban különbözött az előzőtől, hogy az abból kihagyott magyarázatok is helyet kaptak benne. A 2., javított, bővített kiadás 1983-ban hagyta el a nyomdát. A két kiadás közötti különbségek az interneten is megtekinthetők (6. URL). A magyarországi 2. kiadás az angol 2. kiadás után készült el, és az abban foglalt változtatásokat vette át, a 3. pedig a magyar szöveg további javításait tartalmazza. A következő táblázatban a félkövérrel szedett szöveg azt jelöli, hogy a szerző nem az általa leggyakrabban használt igét alkalmazta, kivéve, amikor ezt az ige angol fordításának a változása indokolja. Az első magyar kiadásban az ige néhány helyen rendhagyó módon az alany elé került, ezeket megjelöltem. 
Bakaja Zoltán:

Átváltási müveletek a beszélőjelölőnek nevezett szanszkrit idézö mondat angol és magyar nyelvü fordításaiban

Argumentum 15 (2019), 755-783

Debreceni Egyetemi Kiadó

DOI: 10.34103/ARGUMENTUM/2019/4

\begin{tabular}{|c|c|c|c|c|}
\hline \multicolumn{5}{|c|}{$\begin{array}{c}\text { Bhaktivedanta Swami Prabhupāda } \\
\text { Bhagavad-gītā As It Is. }\end{array}$} \\
\hline & \multicolumn{2}{|c|}{ Angol } & \multicolumn{2}{|c|}{ Magyar } \\
\hline Versszám & 1. kiadás & 2. kiadás & 1. kiadás & 2. / 3. kiadás \\
\hline 1.1 & said & said & így szólt & így szólt \\
\hline 1.2 & said & said & így felelt & így szólt \\
\hline 1.21 & said & said & szólt & így szólt \\
\hline 1.24 & said & said & folytatta & így szólt \\
\hline 1.28 & said & said & szólt & szólt / így szólt \\
\hline 1.46 & said & said & mondta & mondta \\
\hline 2.1 & said & said & mondta & mondta \\
\hline 2.2 & said & said & szólt & így szólt \\
\hline 2.4 & said & said & szólt & így szólt \\
\hline 2.9 & said & said & folytatta & szólt \\
\hline 2.11 & said & said & Szólt & így szólt \\
\hline 2.54 & said & said & kérdezte & így szólt \\
\hline 2.55 & said & said & válaszolt & így szólt \\
\hline 3.1 & said & said & szólt & így szólt \\
\hline 3.3 & said & said & szólt & így szólt \\
\hline 3.36 & said & said & szólt & így szólt \\
\hline 3.37 & said & said & így válaszolt & így szólt \\
\hline 4.1 & said & said & szólt & így szólt \\
\hline 4.4 & said & said & így kérdezett & így szólt \\
\hline
\end{tabular}

\begin{tabular}{|c|c|c|c|c|}
\hline \multicolumn{5}{|c|}{$\begin{array}{c}\text { Bhaktivedanta Swami Prabhupāda } \\
\text { Bhagavad-gītā As It Is. }\end{array}$} \\
\hline & \multicolumn{2}{|c|}{ Angol } & \multicolumn{2}{|c|}{ Magyar } \\
\hline Versszám & 1. kiadás & 2. kiadás & 1. kiadás & 2. / 3. kiadás \\
\hline 4.5 & said & said & így válaszolt & így válaszolt \\
\hline 5.1 & said & said & szólt & így szólt \\
\hline 5.2 & said & replied & így válaszolt & így válaszolt \\
\hline 6.1 & said & said & szólt & így szólt \\
\hline 6.33 & said & said & szólt & így szólt \\
\hline 6.35 & said & said & szólt & így szólt \\
\hline 6.37 & said & said & kérdezett & így szólt \\
\hline 6.40 & said & said & így válaszolt & így válaszolt \\
\hline 7.1 & said & said & szólt & így szólt \\
\hline 8.1 & inquired & inquired & így kérdezett & így kérdezett \\
\hline 8.3 & replied & said & ekképpen válaszolt & így szólt \\
\hline 9.1 & said & said & szólt & így szólt \\
\hline 10.1 & said & said & szólt & így szólt \\
\hline 10.12 & said & said & szólott & így szólt \\
\hline 10.19 & said & said & szólott & így szólt \\
\hline 11.1 & said & said & szólott & így szólt \\
\hline 11.5 & said & said & szólt (az alany előtt) & így szólt \\
\hline 11.9 & said & said & szólt & mondta \\
\hline 11.15 & said & said & szólt & szólt \\
\hline
\end{tabular}


Bakaja Zoltán:

Átváltási müveletek a beszélőjelölőnek nevezett szanszkrit idézö mondat angol és magyar nyelvü forditásaiban

Argumentum 15 (2019), 755-783

Debreceni Egyetemi Kiadó

DOI: 10.34103/ARGUMENTUM/2019/4

\begin{tabular}{|c|c|c|c|c|}
\hline \multicolumn{5}{|c|}{$\begin{array}{c}\text { Bhaktivedanta Swami Prabhupāda } \\
\text { Bhagavad-gītā As It Is. }\end{array}$} \\
\hline & \multicolumn{2}{|c|}{ Angol } & \multicolumn{2}{|c|}{ Magyar } \\
\hline Versszám & 1. kiadás & 2. kiadás & 1. kiadás & 2. / 3. kiadás \\
\hline 11.32 & said & said & szólt (az alany előtt) & így szólt \\
\hline 11.35 & said & said & $\begin{array}{l}\text { igy szólt (az alany } \\
\text { elött) }\end{array}$ & így szólt \\
\hline 11.36 & - & said & - & így szólt \\
\hline 11.47 & said & said & szólt & így szólt \\
\hline 11.50 & said & said & e szavakkal fordult & $\begin{array}{ll}\text { e } & \text { szavakkal } \\
\text { fordult } & \\
\end{array}$ \\
\hline 11.51 & said & said & így szólt & így szólt \\
\hline 11.52 & said & said & szólt (az alany előtt) & így szólt \\
\hline 12.1 & inquired & inquired & így kérdezett & így kérdezett \\
\hline 12.2 & said & said & szólt & így szólt \\
\hline 13.1 & said & said & Szólt & szólt \\
\hline 13.2 & said & said & így válaszolt & így válaszolt \\
\hline 14.1 & said & said & szólt & így szólt \\
\hline 14.21 & inquired & inquired & kérdezett & így kérdezett \\
\hline 14.22 & said & said & így válaszolt & így válaszolt \\
\hline 15.1 & said & said & szólt (az alany előtt) & így szólt \\
\hline 16.1 & said & said & szólott & így szólt \\
\hline 17.1 & inquired & inquired & kérdezett & így kérdezett \\
\hline
\end{tabular}

\begin{tabular}{|c|c|c|c|c|}
\hline \multicolumn{5}{|c|}{$\begin{array}{c}\text { Bhaktivedanta Swami Prabhupāda } \\
\text { Bhagavad-gītā As It Is. }\end{array}$} \\
\hline & \multicolumn{2}{|c|}{ Angol } & \multicolumn{2}{|c|}{ Magyar } \\
\hline Versszám & 1. kiadás & 2. kiadás & 1. kiadás & 2. / 3. kiadás \\
\hline 17.2 & said & answered & szólott & így szólt \\
\hline 18.1 & said & said & szólt & így szólt \\
\hline 18.2 & said & said & szólott & így szólt \\
\hline 18.73 & said & said & szólt & szólt / így szólt \\
\hline 18.74 & said & said & szólt & szólt \\
\hline
\end{tabular}

8. táblázat. A Bhagavad-gītā As It Is angol és magyar nyelvü kiadásai 
Azt látjuk a táblázatból, hogy az angol 2. kiadás a jelölő igéjének tekintetében mindössze négy helyen változott, a magyar azonban jelentős átalakuláson ment keresztül. A 2. magyar kiadásban a betoldást alkalmazó változat nyert teret, $\mathrm{s}$ az elsőhöz képest jóval kevesebbszer él a konkretizálás lehetőségével.

Ahogy azt a bevezetésben írtam, az ösztönzött erre a kutatásra, hogy a várakozásommal ellentétben jó néhány angol fordításban találkoztam az idéző ige konkretizálásával, ugyanakkor több olyan magyar kiadás is van, amelyben nem fordul elö. Klaudy szerint az indoeurópai nyelvekről magyarra való fordításkor gyakori konkretizálásnak stilisztikai okai vannak, s a célja a monotonitás elkerülése (1999: 49). Itt mégis azt látjuk, hogy a Bhagavad-gītā szépirodalmi fordításai között eggyel sem találkozunk, amelyben a konkretizálás elöfordulna. Ennek okát talán a verses fordítások formaközpontú szemléletében kell keresni. A Gītā időmértékes verselésű költemény, a beszélőjelölő azonban kívül áll a versszakokon és nem is mértékben íródott. Az általános jelentésü idéző ige megtartása akár ennek a versenkívüliségnek az érzékeltetésére is jó lehet. Saját fordításomban azt a célt tüztem ki magam elé, hogy mindig ragaszkodjak az eredeti versmértékhez, azokon a helyeken pedig, ahol a verselés eltér az upajāti versmérték leggyakrabban leírt változatától, az adott versszakok pontos ritmusát kövessem. Így tettem a beszélőjelölö igéje esetében is, s olyan megoldást választottam, amelyben a magyar megfelelö legalább hangzásában követi a szanszkrit eredeti ritmusát.

\section{6 Összefoglalás}

A szanszkrit beszélőjelölő az idéző mondat olyan formája, amelyet a Mahābhāratában, az upaniṣadok némelyikében és a purānákban használnak. Ez a '(A nagytiszteletü) X. Y. mondta' jelentésü formula a Bhagavd-gītāban 60-szor fordul elö, a szerkezete alany+idéző ige vagy jelzö+alany+idéző ige, a funkciója pedig a beszélő személyének megmutatása. A Bhagavad-gītāban négy idéző mondatot alkot, ezek a: (1) dhrtarāșțta uvāca, (2) sañjaya uvāca, (3) arjuna uvāca és a (4) śrī-bhagavān uvāca.

Tanulmányomban egy 33 teljes, illetve részleges fordítást tartalmazó angol, magyar és hindi nyelvü korpuszban vizsgáltam meg a jelölő fordítása során alkalmazott átváltási müveleteket. A korpuszon belül 13 mü volt magyar nyelvü. A magyar korpusz kötetei közül csak Baktay, Kégl és Vekerdi, valamint az én fordításom készült a szanszkrit eredetiből, a többi forrásnyelve az angol vagy a magyar volt.

A tanulmány egy-egy fejezetben mutatta be a jelölő jelzőjének, alanyának és igéjének fordítása során alkalmazott átváltási müveleteket. A beszélőjelölő jelzőjének angol fordításakor a kihagyást, az idegen szóként való átvételt és az egyszerü behelyettesítést figyeltem meg. A magyar fordítások elemzésénél figyelembe kellett vennem, hogy jó részük forrásszövege angol volt, így az alkalmazott átváltási müveleteket máshogy kellett értékelnem, mintha a szanszkrit eredetivel hasonlítottam volna öket össze. Az itt alkalmazott müveletek között kihagyást, egyszerü behelyettesítést, valamint jövevény- és idegen szóként való átvételt találunk.

A jelölő alanya angol fordításainak elemzése során idegen szóként való átvételt, jövevényszókénti átvételt, a névelő betoldását és konkretizálást találtam. A magyar fordításokban idegen szóként való átvételt, jövevényszókénti átvételt, konkretizálást, egyszerü behelyettesítést, a névelő kihagyását, grammatikai áthelyezést és intralingvális átvételt fedeztem fel. 
A korpuszban a jelölő igéjének a fordítása mutatta a legnagyobb változatosságot. Az uvāca angol fordítása során nyomatékosító elem betoldását, grammatikai kihagyást, konkretizálást, és egyszerü behelyettesítést írtam le. A magyar fordítás vizsgálata során egyszerü behelyettesítést, nyomatékosító elem betoldását, lexikai konkretizálást, az ige formájának megváltoztatását, és grammatikai kihagyást fedeztem fel.

A kutatást Sebestyén angol forrásszövegének, illetve Sridhar bengáli nyelvü fordításának a vizsgálata tehetné teljessé, így a korpusz fordítói által használt összes átváltási müveletről biztosat állíthatnánk.

\section{Források}

Abhinavagupta (2012): Gītārthasaimgraha. Budapest: Perisca Kiadó. (Virág L. ford.)

Abhinavagupta (2004): Abhinavagupta's commentary on the Bhagavad Gita: Gittārthasamgraha. Varanasi: Indica Books. (Marjanovic, B. ford.)

Bakaja, Z. (ford.) (2016): Bhagavad-gitá részlet. In: Hetényi Zs. (szerk.): 5Pofon: Antológia müfordítás-antológia. Budapest: ELTE BTK, 8-22.

Baktay, E. (2013): A Magasztos Szózata. Budapest: Filosz Kiadó.

Bakos, A. \& Bakos J. E. (2017): Bhagavad gītā. Budapest: Dhanvantara Kiadó.

Baladeva (é. n.): Gìtā Bhūṣaṇa. Chennai: Sri Vaikunta Enterprises. (Bhānu Swāmī ford.)

Besant, A. \& Bhagavân, D. (ford.) (1905): The Bhagavad-gītā. London, Benares: Theosophical Publishing Society.

Bhaktivedanta Swami Prabhupāda, A. C. (1972): Bhagavad-gītā As It Is. New York: Collier Books, London: Collier Macmillan Publishers.

Bhaktivedanta Swami Prabhupāda, A. C. (2001): A Bhagavad-gìtā úgy, ahogy van. h. n.: The Bhaktivedanta Book Trust. (Dvārakeśa, Dāsa és mások ford.)

Bhaktivedanta Swami Prabhupāda, A. C. (2014): A Bhagavad-gìtā úgy, ahogy van. h. n.: The Bhaktivedanta Book Trust. (Dvārakeśa, Dāsa és mások ford.)

Bhaktivedanta Swami Prabhupāda, A. C. (2015): Bhagavad-gītā As It Is. h. n.: The Bhaktivedanta Book Trust.

Bhaktivedanta Swami Prabhupāda, A. C. (é. n.): Az eredeti Bhagavad-gìtāa Vaduz: The Bhaktivedanta Book Trust (Dvārakeśa Dāsa ford.).

Bhaktivedanta Swami, A. C. (1968): The Bhagavad Gita As It Is. London: Collier Macmillan Ltd.

Bhaktivinoda (2006): Srīmad Bhagavad-gìtā. Vrindaban: Rasbihari Lal \& Sons. (Bhumipati, D. ford.)

Czuczor, G. \& Fogarasi, J. (1865): A magyar nyelv szótára, Harmadik kötet. Pest.

Gömöryné Maróthy, M. (ford.) (1924): Bhagavad-Gitá az isteni ének. Budapest: Légrády Nyomda és Könyvkiadó.

Ithamar, T. (2010): Exploring the Bhagavad Gìtā Philosophy, Structure and Meaning. Farnham: Ashgate Publishing Limited; Burlington: Ashgate Publishing Company.

Kégl, S. (1910): Bhagavadgîtâ. Budapest: Magyar Tudományos Akadémia.

Lakatos, I. \& Vekerdi, J. (ford.) (1987): A magasztos szózata Bhagavad-gitá. Budapest: Európa Kiadó.

Macnicol, N. (ed.) (1938): Hindu Scriptures. London: J. M. Dent \& Sons Limited. New York: Dutton \& Co. Inc. 
Maharishi, M. (1967): Bhagavad-Gita: A New Translation and Commentary Chapters 1-6. London: International SRM Publications.

Maharishi, M. (2016): A Bhagavad-gitá: Új formátumban és új magyarázattal. h. n.: Vaszistha Kft. (Dienes I. ford.)

Monier-Williams, M. (ed.) (2011): A Sanskrit-English Dictionary. Delhi: Motilal Banarsidass Publishers.

Nārāyaṇa Goswāmī̄, B. (2011): Śrīmad Bhagavad-gītā. Vṛndāvana, New Delhi, San Francisco: Gaudiya Vedanta Publications.

Országh, L. \& Magay, T. (szerk.) (2009): Angol-magyar nagyszótár. Budapest: Akadémiai Kiadó.

Sebestyén, E. (ford.) (2000): Bhagavad Gita. Budapest: Sri Sathya Sai Baba Szervezet Magyarországi Központja.

Sivananda (2000): Bhagavad Gita. Shivanandanagar: The Divine Life Society. http://www.dlshq.org/download/bgita.pdf

Sivánanda (é. n.: Bhagavad Gítá. H.n.: The Divine Life Society. (Szabó Á. ford.)

Sridhar Dev-Goswami, B. R. (2006): Śrimad Bhagavd-gìtā: The Hidden Treasure of the Sweet Absolute. Nabadwip: Sri Chaitanya Saraswat Math. (Sri Swarupananda D. ford.)

Śrīdhara Deva Gosvāmī, B. R. (2003): Bhagavad-Gìtā: Az Édes Abszolút rejtett kincse. h. n.: Harmónia Alapítvány. (Dóka R. ford.)

Szerdahelyi, I. \& Tóth, E. (ford.) (1965): Mahábhárata. Budapest: Európa Könyvkiadó.

Tsering, K. (2003): A Bhagavad Gítá ahogyan én látom. H. n.: Berkes Attila kiadása.

Vekerdi, J. (ford.) (1997): A Magasztos szózata. Budapest: Terebess Kiadó.

Viśvanātha Cakravartī (2003): Sārārtha-Varșiṇī-Tīkā. Chennai: Sri Vaikunta Enterprises. (Bhānu Swāmī ford.)

Wilkins, Ch. (1785): Bhagvat-geeta or Dialogues of Kreeshna and Arjoon; in eighteen lectures; with notes. London: C. Nourse.

\section{Online források}

\section{URL}

Nārāyaṇa Gosvāmī, B. Śrīmad Bhagavad-gītāa.

http://www.purebhakti.com/resources/ebooks-a-magazines-mainmenu-63/bhakti-

books/hindi/133-bhagavad-gita-1/file.html (Az utolsó megtekintés időpontja 2017.06.17.).

2. URL

https://hu.glosbe.com/hi/hu/\%E0\%A4\%B6\%E0\%A5\%8D\%E0\%A4\%B0\%E0\%A5\%80 (Az utolsó megtekintés időpontja 2017.06.17.).

3. URL

https://www.vedabase.com/en/synonyms-

index?original_op=word\&original=\%C5\%9Br\%C4\%AB\&translation_op=contains\&translati on=blessed (Az utolsó megtekintés időpontja 2017.06.17.).

4. URL

Sridhar Swami, B. R. Srimad Bhagavad-gita: The Hidden Treasure of the Sweet Absolute. https://shloki.ru/bg/sridharmj-1st-eng+sridharmj-2006-eng (Az utolsó megtekintés időpontja 2017.06.15.). 


\section{URL}

Szabó, L. (ford.) Bhagavad-gitá, XI. ének.

https://terebess.hu/keletkultinfo/bhagav9.html (Az utolsó megtekintés időpontja 2017.06.15.).

6. URL

Bhaktivedanta Swami Prabhupāda, A. C. 1972/1983. Bhagavad-gītā As It Is.

http://vanisource.org/viewdiff/compare.php?domain=vanisource.org\&book=BG\&verse $=1.1 \&$ version1=1972\&version2=1983\%2B (Az utolsó megtekintés időpontja 2017.06.15.).

\section{Irodalom}

Klaudy, K. (2018): Az átváltási műveletek rendszere. Modern Nyelvoktatás 24.2-3, 5-16.

Klaudy, K. (1999): Bevezetés a fordítás gyakorlatába. Budapest: Scholastica.

Klaudy, K. \& Simigné, F. S. (2000): Angol-magyar fordítástechnika. Budapest: Nemzeti Tankönyvkiadó.

Körtvélyesi, T. (2006): Szanszkrit nyelvtan. Budapest: A Tan Kapuja Buddhista Főiskola.

\section{Köszönetnyilvánítás}

Köszönöm a tanulmány anonim lektorának, hogy értékes észrevételeivel segítette a munkámat.

Bakaja Zoltán

ELTE BTK Irodalomtudományi Doktori Iskola

1088 Budapest

Múzeum krt. 4/A, 3. em., 319.

zoltan@bakaja.hu 